\title{
The Defining Positive Role of High Cell Temperature on the Efficiency of a Multicrystalline Solar Photovoltaic Array
}

\author{
Shalini Garg \\ Government Polytechnic College \\ Jodhpur, India
}

\author{
Arun J. B. \\ Teacher's Training Center \\ Jodhpur, India
}

\begin{abstract}
The progress in solar photovoltaic cell technology has led to development of several different types of cell varying widely in efficiency, performance and cost but still multicrystalline cell is the most widely used commercial cell. The maximum laboratory efficiency of multicrystalline cell is about $22 \%$ which is hardly attainable in field due to entirely different and variable climatic conditions. Increasing the efficiency in real field conditions is one of the greatest challenges of solar photovoltaics. Evaluating effect of major climatic parameters on the efficiency in the real field conditions can pave the way for increasing the efficiency of solar photovoltaic power plants. This paper evaluates the relative effect and role of irradiance and cell temperature acting simultaneously on solar cell conversion efficiency and DC power efficiency of a multicrystalline photovoltaic array for the climatic conditions of Western Rajasthan. It brings forward for the first time ever the defining positive role of cell temperature on the solar cell conversion efficiency and DC power efficiency of a multicrystalline photovoltaic array in contrast to literature and research papers all which show efficiency decreases with increase in temperature.
\end{abstract}

\section{General Terms}

Solar Irradiance; Efficiency; Real Field Climatic Conditions; Grid Connected PV Power Plant; Western Rajasthan.

\section{Keywords}

Solar Cell Conversion Efficiency; DC Power Efficiency; Energy Yield; Multicrystalline PV Array; Cell Temperature; Plane Of Array Irradiance (POA).

\section{INTRODUCTION}

The solar cell conversion efficiency and the power output of PV plant are specified at STC conditions which are far different from actual values. The reason for the vast difference is that the STC conditions rarely exists, the performance of technological parameters viz solar cell conversion efficiency and DC power efficiency are evaluated in laboratory conditions which are entirely different from real field conditions. Further evaluation is based on models developed on theoretical basis and in few papers simultaneous effect of irradiance and cell temperature has not been considered although they go hand in hand.

Literature and several research papers show that both power output and efficiency decrease with increase in temperature [1, $2,3,4,5,6,7,8,9,10]$. Elminir et al. showed that temperature coefficient for current, power and efficiency were about +40 $\mu \mathrm{A} /{ }^{\circ} \mathrm{C},-0.4 \mathrm{~mW} /{ }^{\circ} \mathrm{C}$ and $-0.4 \% /{ }^{\circ} \mathrm{C}$ respectively [2]. Radziemska reported $-0.65 \% /{ }^{\circ} \mathrm{K}$ and $-0.08 \% /{ }^{\circ} \mathrm{K}$ as the temperature coefficient for power output and solar cell conversion efficiency respectively [3]. Skoplaki et al. concluded that power output and efficiency decrease linearly with increase in cell temperature [4]. Milosavljevic et al. investigated efficiency of monocrystalline solar photovoltaic (SPV) power plant and found that increase in solar radiation increases cell temperature which in turn decreases open circuit voltage reducing efficiency [5]. Power temperature coefficient of $-0.5 \% /{ }^{\circ} \mathrm{C}$ for polycrystalline silicon and $-0.25 \% /{ }^{\circ} \mathrm{C}$ for amorphous silicon was reported by King et al. while $-0.4 \% /{ }^{\circ} \mathrm{C}$ for crystalline silicon was reported by Sick and Erge [6]. Cotfas et al. found that power coefficient for different types of cell varied between $-0.14 \%{ }^{\circ} \mathrm{C}$ to $-0.47 \% /^{\circ} \mathrm{C}$ [7]. Kamuyu et al. showed that efficiency decreases with increase in temperature and that Floating PV system produce $10 \%$ more energy as compared to land-based system due to cooling effect of water [8].

Few researchers have shown that energy yield in summers that is at higher temperature is higher due to dominating effect of irradiance despite decrease in efficiency with increase in temperature $[9,10]$. Touati et al. investigated that decrease in efficiency was about $0.15 \% /{ }^{\circ} \mathrm{C}$ and $0.43 \% /{ }^{\circ} \mathrm{C}$ for monocrystalline and amorphous $\mathrm{PV}$ respectively although maximum power was generated during peak hours at high temperature [11]. Mazzeo et al. mentioned that concentrating photovoltaic system have greater conversion efficiency and consequently higher electricity production compared to conventional system. It also showed that production in summers was far greater than in winters [12].

Positive effect of temperature on efficiency has been reported by few researchers $[11,13]$. Garg JB showed defining positive role of cell temperature on DC power and energy yield but effect on the solar cell conversion efficiency was not considered [14]. This paper presents visual representation of relative contribution of irradiance and cell temperature acting simultaneously on solar cell energy conversion efficiency $\left(E_{1}\right)$ and DC power efficiency $\left(\mathrm{E}_{2}\right)$ and evaluates relative contribution and role of irradiance and cell temperature on $\mathrm{E}_{1}$ and $E_{2}$. The evaluation is based on the data of a multicrystalline PV array installed in Western Rajasthan. It brings forward for the first time ever the defining positive role of cell temperature on the efficiency in contrast to negative effect of high cell temperature.

A solar cell's energy conversion efficiency ( $\eta$, "eta"), is the percentage of power converted from absorbed light to electrical energy when connected to an electrical circuit that is ratio of output power to input power and is given by equation 1 . It is measured at STC $[9,15,16]$. 
1. $\quad \eta=\mathrm{P}_{\mathrm{m}} /\left(\mathrm{E}^{*} \mathrm{~A}_{\mathrm{c}}\right)$

Where

$\mathrm{P}_{\mathrm{m}}=$ maximum power in $\mathrm{kW}$,

$\mathrm{E}=$ Input light irradiance at STC that is $1 \mathrm{~kW} / \mathrm{m}^{2}$,

$\mathrm{A}_{\mathrm{c}}=$ surface area of the solar cell in $\mathrm{m}^{2}$.

Power output efficiency $\left(\eta_{p}\right)$ in $\%$ as mentioned by N. Amin, et al. and Ghazali et al. is given by equation $2[17,18]$.

2. $\eta_{\mathrm{p}}=$ Power output efficiency $(\%)$

$\eta_{\mathrm{p}}=\left(P_{\text {mea }} / P_{\max }\right) * 100 \%$

Where

$P_{\text {mea }}=$ Average power output (W) measured on site in the given period,

$P_{\max }=$ Maximum power output of panel.

The solar cell conversion efficiency $\left(\mathrm{E}_{1}\right)$ at time $\mathrm{t}$ and power output efficiency $\left(\mathrm{E}_{2}\right)$ at time $\mathrm{t}$ in $\%$ are defined as follows

3. $\mathrm{E}_{1}=\left\{\mathrm{P}_{\mathrm{t}} /\left(\mathrm{E}^{*} \mathrm{~A}_{\mathrm{c}}\right)\right\} * 100$

Where

$\mathrm{P}_{\mathrm{t}}=$ Power output at time $\mathrm{t}$;

$\mathrm{E}=$ Input light irradiance at STC that is $1 \mathrm{~kW} / \mathrm{m}^{2}$,

$\mathrm{A}_{\mathrm{c}}=$ surface area of the solar cell in $\mathrm{m}^{2}$.

4. $\mathrm{E}_{2}=\left(\mathrm{P}_{\mathrm{t}} / \mathrm{P}_{\max }\right) * 100 \%$

Where

$\mathrm{P}_{\mathrm{t}}=$ Power output at time $\mathrm{t}$;

$\mathrm{P}_{\max }=$ Maximum power output of panel at STC that is maximum rated value of the array.

As per the Photovoltaics Report, prepared by Fraunhofer institute for Solar Energy Systems, the record lab efficiency for monocrystalline and multicrystalline silicon cell are $26.7 \%$ and $22.3 \%$ respectively. For the modules with concentrator technology efficiency up to $38.9 \%$ has been achieved [19]. The solar cell conversion efficiency for the module investigated as specified by the manufacturer at STC is $16.936 \%$.

\section{METHODOLOGY}

The module used for analysis is a multicrystalline module having specifications as shown in table 1 .

Table 1. The module specifications at STC (Standard Test Conditions), for the $5 \mathrm{MW}$ grid connected multicrystalline PV power plant located at Ramgarh.

\begin{tabular}{|c|c|c|}
\hline S. No. & Electrical Characteristics & Values \\
\hline 1. & Maximum power $\mathrm{P}_{\operatorname{mpp}} / \mathrm{P}_{\max }$ & $247.39 \mathrm{~W}$ \\
\hline 2. & Voltage at $\mathrm{P}_{\max }, \mathrm{V}_{\mathrm{mpp}}$ & $30.64 \mathrm{~V}$ \\
\hline 3. & Current at $\mathrm{P}_{\max }, \mathrm{I}_{\mathrm{mpp}}$ & $8.07 \mathrm{~A}$ \\
\hline 4. & Open circuit voltage $\mathrm{V}_{\mathrm{oc}}$ & $37.67 \mathrm{~V}$ \\
\hline 5. & Short circuit current $\mathrm{I}_{\mathrm{sc}}$ & $8.26 \mathrm{~A}$ \\
\hline 6. & Temperature coefficient of $\mathrm{P}_{\max }$ & $-0.447 \% /{ }^{\circ} \mathrm{K}$ \\
\hline 7. & Temperature coefficient of $\mathrm{V}_{\mathrm{oc}}$ & $-0.353 \% /{ }^{\circ} \mathrm{K}$ \\
\hline
\end{tabular}

\begin{tabular}{|c|c|c|}
\hline 8. & Temperature coefficient of $\mathrm{I}_{\mathrm{sc}}$ & $0.104 \% /{ }^{\circ} \mathrm{K}$ \\
\hline 9. & Power Tolerance & $-0 /+5 \mathrm{~W}$ \\
\hline 10. & Fuse rating & $15 \mathrm{~A}$ \\
\hline 11. & Maximum System Voltage & $1000 \mathrm{~V}$ \\
\hline
\end{tabular}

2.1 The analysis is based on the average reading of five array with maximum rated DC voltage, maximum rated DC current and maximum rated DC power being equal to $735.36 \mathrm{~V}(24 * 30.64), 161.4 \mathrm{~A}(20 * 8.07)$ and $118.687 \mathrm{~kW}$ $(735.36 * 161.4)$ respectively.

2.2 The solar conversion efficiency $\left(\mathrm{E}_{1}\right)$ and $\mathrm{DC}$ power efficiency $\left(E_{2}\right)$ at time $t$ are evaluated and are plotted with respect to time along with variation in POA and cell temperature with respect to time to observe simultaneous effect of irradiance and cell temperature for different days of the year chosen randomly. The evaluated data extends from September 2015 to July 2016.

2.3 The solar cell conversion efficiency, DC power efficiency, DC voltage, DC current and cell temperature are represented by $E_{1}, E_{2}, V_{d c}, I_{d c}$ and $T_{c}$ respectively. The corresponding units for $\mathrm{E}_{1}, \mathrm{E}_{2}, \mathrm{~V}_{\mathrm{dc}}, \mathrm{I}_{\mathrm{dc}} \mathrm{POA}$ and $\mathrm{T}_{\mathrm{c}}$ are $\%$, $\%, \mathrm{~V}, \mathrm{~A}, \mathrm{~W} / \mathrm{m}^{2}$ and ${ }^{\circ} \mathrm{C}$.

2.4 The irradiance used is plane of array irradiance and is represented by POA. The variations in graphs are followed by respective dates for example E1-18-10-15 represents variations of $\mathrm{E}_{1}$ for $18^{\text {th }}$ October 2015 and E222-2-16 represents variations of $\mathrm{E}_{2}$ for $22^{\text {nd }}$ February 2016.

2.5 The monitored period is divided into four seasons namely Post monsoon, Winter, Spring and Summer.

2.6 The average value of $\mathrm{E}_{1}, \mathrm{E}_{2}$, cell temperature and POA is also evaluated and is represented by $\mathrm{E}_{1 \mathrm{av}}, \mathrm{E}_{2 \mathrm{av}}, \mathrm{T}_{\mathrm{cav}}$ and $\mathrm{POA}_{\mathrm{av}}$ respectively. The energy yield of the day is also evaluated.

2.7 The effect of dust, wind, humidity and other environmental parameters has not been considered.

\section{EXPERIMENTAL DATA ANALYSIS}

Relative contribution and role of cell temperature and irradiance acting simultaneously on efficiency is observed and evaluated for various seasons by plotting variations of solar cell conversion efficiency, DC power efficiency, POA and cell temperature with respect to time. To elaborate the significance of voltage variations in comparison to current, variations in the technical parameters viz $\mathrm{E}_{1}, \mathrm{~V}_{\mathrm{dc}}$ and $\mathrm{I}_{\mathrm{dc}}$ with respect to POA are also plotted.

\subsection{Variation of Solar Cell Conversion $\operatorname{Efficiency}\left(\mathbf{E}_{1}\right)$, DC Power Efficiency $\left(\mathbf{E}_{2}\right)$, Cell Temperature and POA with Time for Post Monsoon Season}

The post monsoon season extends from September to October. The two dates $11^{\text {th }}$ September and $18^{\text {th }}$ October of the post monsoon season have been chosen randomly. Variation of $E_{1}$, $\mathrm{V}_{\mathrm{dc}}$ and POA with time for $11^{\text {th }}$ September and $18^{\text {th }}$ October are shown in figure 1 and 3 respectively. Figure 2 and 4 shows variation of $\mathrm{E}_{1}, \mathrm{E}_{2}$ and cell temperature with time for $11^{\text {th }}$ 
September and $18^{\text {th }}$ October respectively. Variations in $\mathrm{E}_{1}$ and $\mathrm{V}_{\mathrm{dc}}$, variations in $\mathrm{E}_{1}$ and $\mathrm{I}_{\mathrm{dc}}$ with respect to POA for $18^{\text {th }}$ October are plotted in figure 5 and 6 respectively.

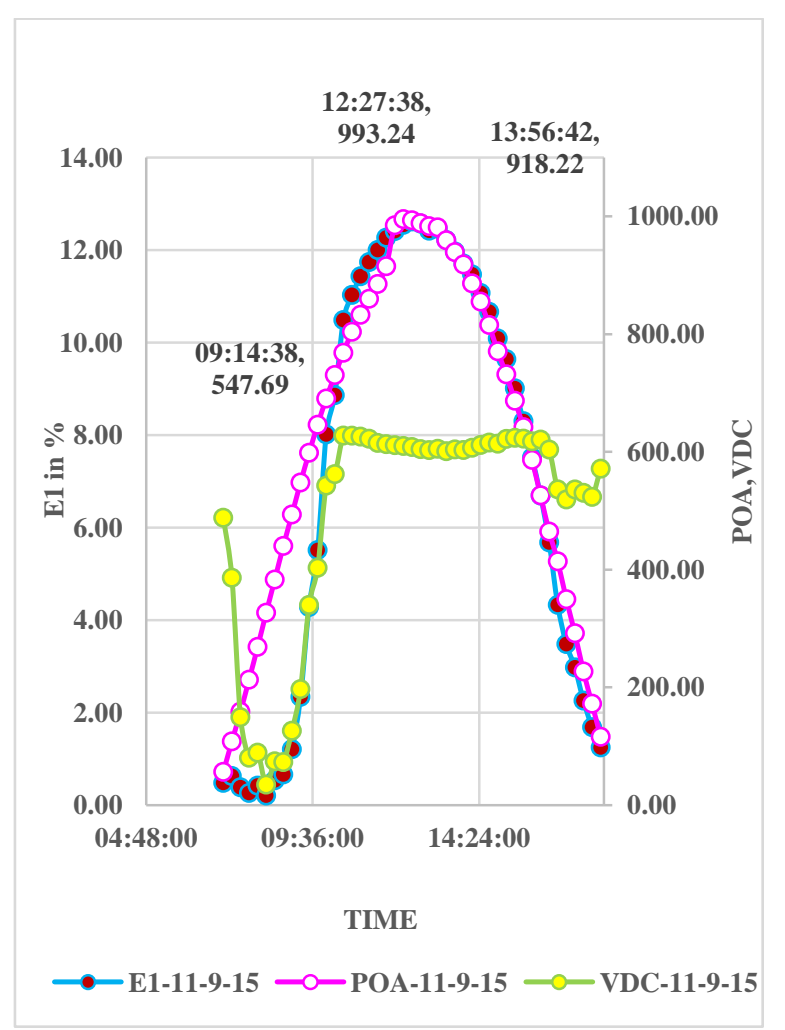

\section{Figure 1: Variation of E1 and POA for $11^{\text {th }}$ September} 2015.

For $11^{\text {th }}$ September the points corresponding to POA are marked in figure 1 and points corresponding to $E_{1}, E_{2}$ and $T_{c}$ are marked in figure 2. Following conclusions can be drawn from figure 1 and 2 .

- With increasing POA as POA increases from $547.69 \mathrm{~W} / \mathrm{m}^{2}$ to $993.24 \mathrm{~W} / \mathrm{m}^{2}$ shown vide figure $1, \mathrm{~T}_{\mathrm{c}}$ increases from $41.71^{\circ} \mathrm{C}$ to $54.46^{\circ} \mathrm{C}, \mathrm{E}_{1}$ increases from $2.34 \%$ to $12.62 \%, \mathrm{E}_{2}$ increases from $13.79 \%$ to $74.49 \%$ as shown vide figure 2 , depicts a significant increase in $\mathrm{E}_{1}$ and $\mathrm{E}_{2}$ with increase in POA and cell temperature.

- With decreasing POA as POA decreases from 993.24 $\mathrm{W} / \mathrm{m}^{2}$ to $918.22 \mathrm{~W} / \mathrm{m}^{2}$ shown vide figure $1, \mathrm{~T}_{\mathrm{c}}$ continues to increase from $54.46^{\circ} \mathrm{C}$ to $56.41^{\circ} \mathrm{C}$ with slight decrease in $\mathrm{E}_{1}$ and $\mathrm{E}_{2}$ but still $\mathrm{E}_{1}$ and $\mathrm{E}_{2}$ as high as $11.71 \%$ and $69.12 \%$ respectively are obtained at $56.41^{\circ} \mathrm{C}$. Thereafter cell temperature, $\mathrm{E}_{1}$ and $\mathrm{E}_{2}$ all decrease with decreasing POA. The slight decrease in $E_{1}$ and $E_{2}$ with decreasing POA and increasing cell temperature is insignificant compared to its value at low temperature.

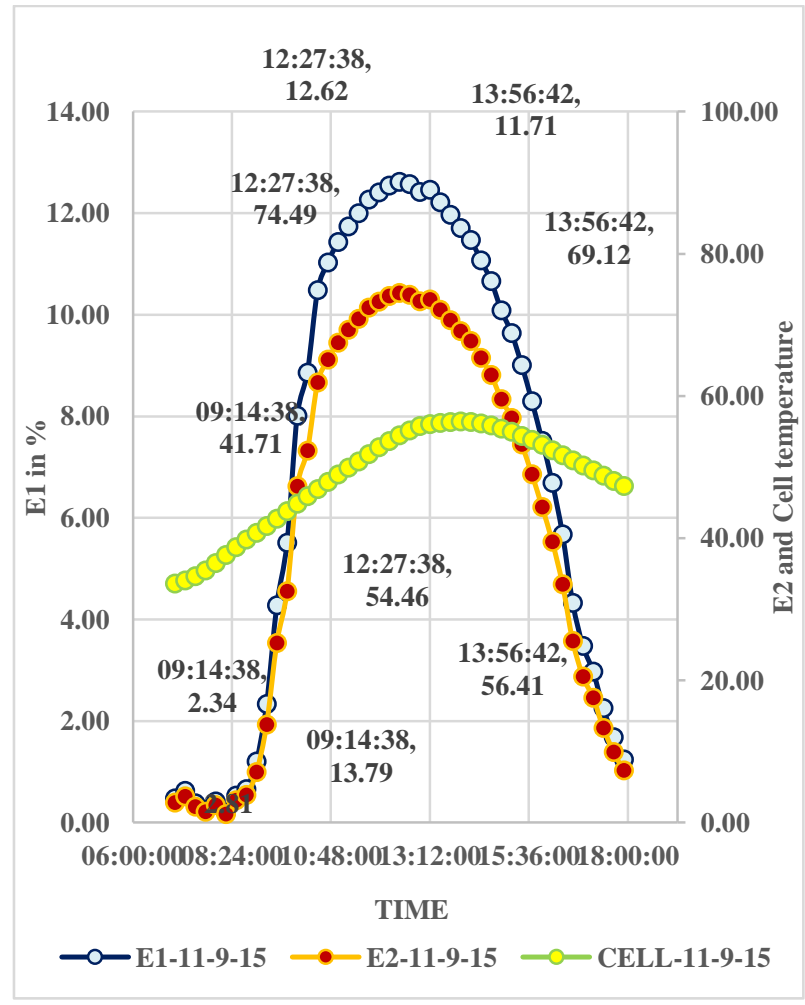

Figure 2: Variation of $E_{1}, E_{2}$ and cell temperature for $11^{\text {th }}$ September 2015.

Similar results are obtained for $18^{\text {th }}$ October and the points corresponding to POA are marked in figure 3 and corresponding to $E_{1}, E_{2}$ and $T_{c}$ are marked in figure 4. It is observed that both DC power conversion efficiency $\left(\mathrm{E}_{2}\right)$ and solar cell conversion efficiency $\left(\mathrm{E}_{1}\right)$ varies in direct proportion to irradiance and cell temperature with $\mathrm{E}_{1}$ and $\mathrm{E}_{2}$ as high as $13.39 \%$ and $79.07 \%$ respectively at cell temperature $57.47^{\circ} \mathrm{C}$ for 18 th October as shown vide figure 4 . For $18^{\text {th }}$ October $\mathrm{E}_{1}$ decreases from $13.39 \%$ to $13.17 \%, \mathrm{E}_{2}$ decreases from $79.07 \%$ to $77.74 \%$ as cell temperature increases from $57.47^{\circ} \mathrm{C}$ to $58.11^{\circ} \mathrm{C}$ and that too due to decrease in POA from 966.90 $\mathrm{W} / \mathrm{m}^{2}$ to $948.16 \mathrm{~W} / \mathrm{m}^{2}$. The slight decrease in $\mathrm{E}_{1}$ and $\mathrm{E}_{2}$ with decreasing POA and increasing cell temperature is insignificant. Figure 1 and 3 show variations in $E_{1}$ follow variations in POA only after $\mathrm{V}_{\mathrm{dc}}$ attains saturation maintaining high and nearly constant value. As $I_{d c}$ varies in direct proportion to POA it can be said that $\mathrm{E}_{1}$ varies in accordance to $I_{d c}$ for nearly constant $V_{d c}$. The fact is further elaborated by plotting variation of $E_{1}$ and $V_{d c}$; variation of $E_{1}$ and $I_{d c}$ with respect to POA in figure 5 and 6 respectively for $18^{\text {th }}$ October. 


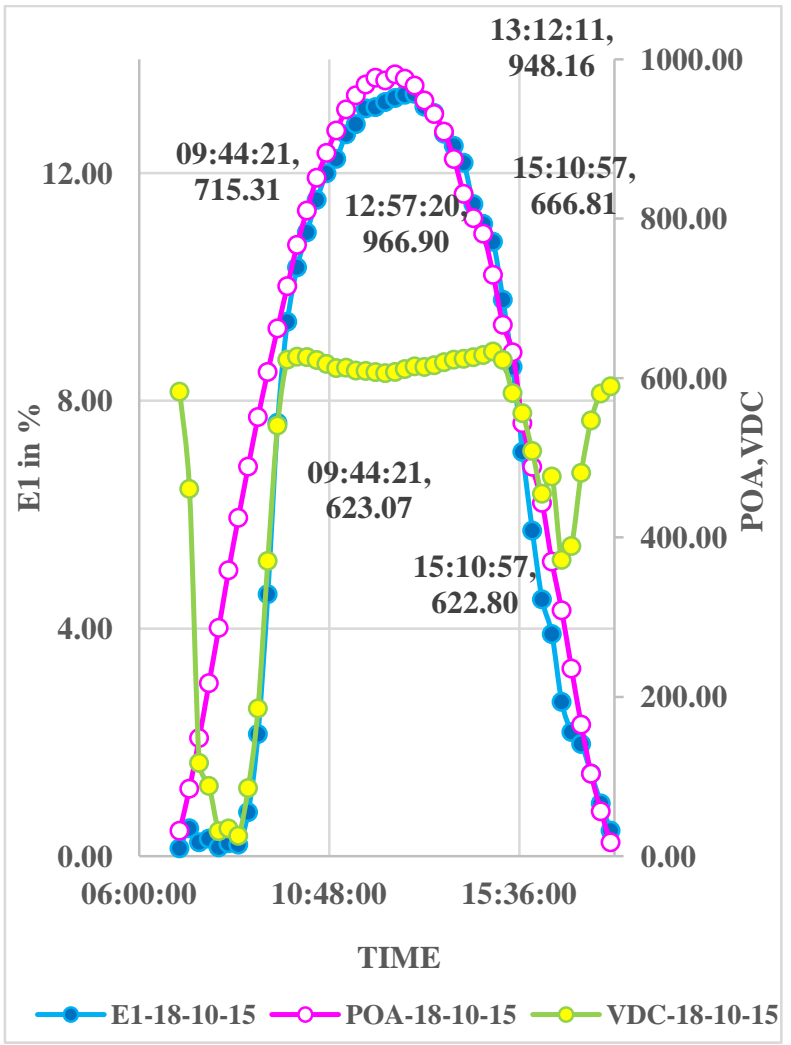

Figure 3: Variation of $E_{1}$ and POA cell temperature for $18^{\text {th }}$ October 2015.

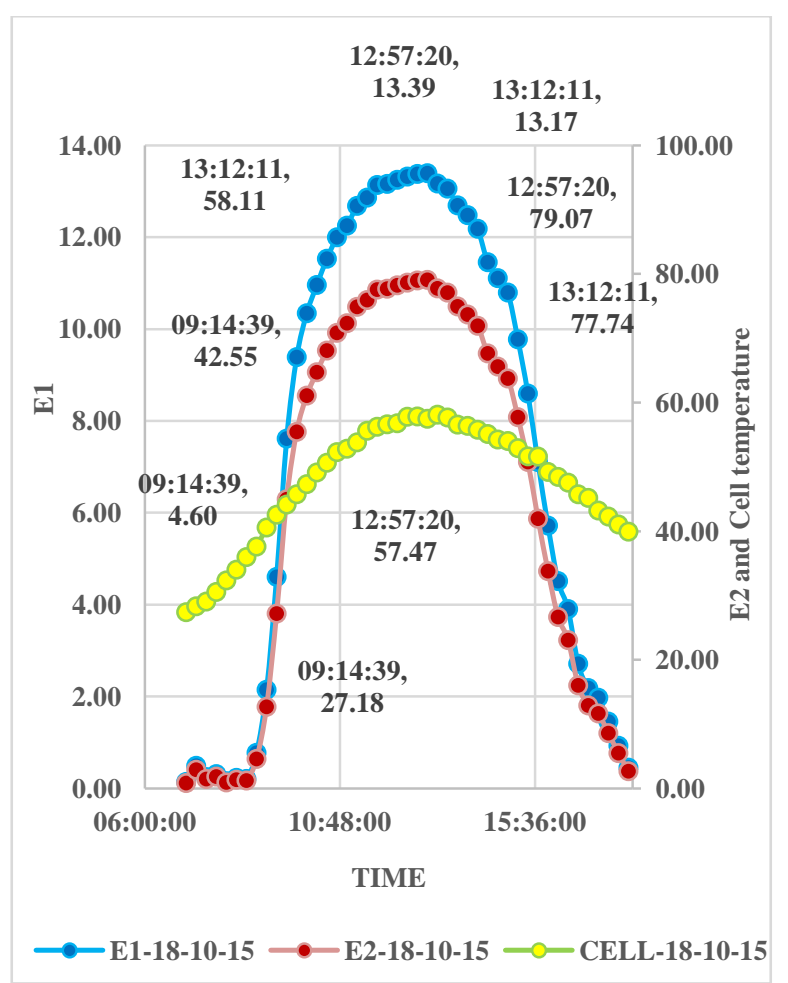

Figure 4: Variation of $E_{1}, E_{2}$ and cell temperature for $18^{\text {th }}$ October 2015.

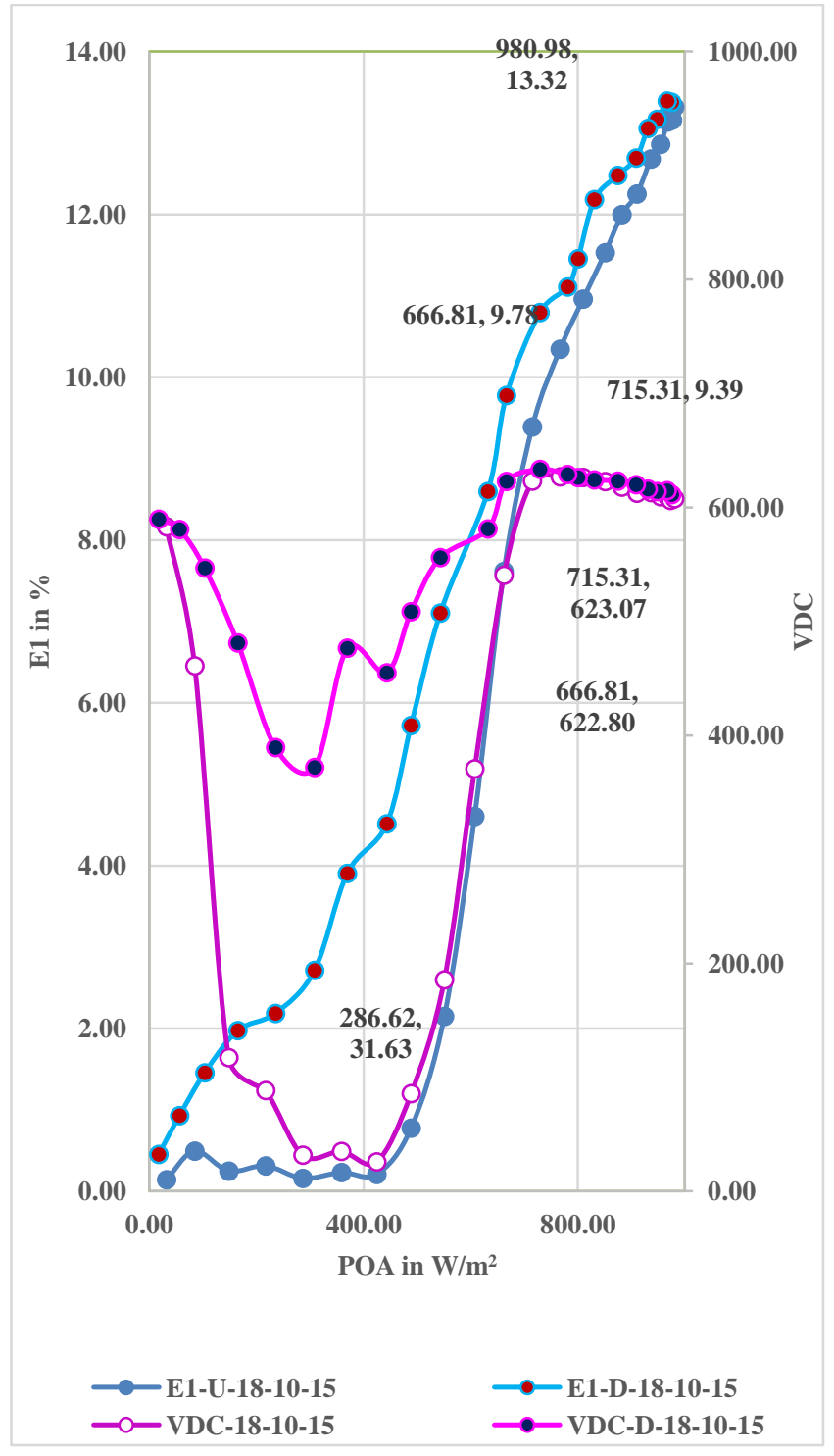

Figure 5: Variation of $E_{1}$ and $V_{d c}$ with respect to POA.

$\mathrm{V}_{\mathrm{dc}}$ attains nearly constant value in the time interval 9:44:21 to 15:10:57 with corresponding $\mathrm{V}_{\mathrm{dc}}$ and POA equal to $623.07 \mathrm{~V}$, $715.31 \mathrm{~W} / \mathrm{m}^{2}$ and $622.80 \mathrm{~V}, 666.81 \mathrm{~W} / \mathrm{m}^{2}$ respectively, shown vide figure 3. As POA increases from $286.62 \mathrm{~W} / \mathrm{m}^{2}$ to 715.31 $\mathrm{W} / \mathrm{m}^{2}$ variation in $\mathrm{E}_{1}$ follow variations in $\mathrm{V}_{\mathrm{dc}}$ shown vide figure 3 and 5. With further increase in POA from 715.31 $\mathrm{W} / \mathrm{m}^{2}$ to $980.98 \mathrm{~W} / \mathrm{m}^{2}$, reducing back to $666.81 \mathrm{~W} / \mathrm{m}^{2}$ with descending sun $E_{1}$ varies linearly with $\mathrm{I}_{\mathrm{dc}}$ as shown vide figure 5 and 6 . With increasing POA both $\mathrm{I}_{\mathrm{dc}}$ and $\mathrm{E}_{1}$ vary linearly with POA, with decreasing POA there is slight change in gradient of $\mathrm{I}_{\mathrm{dc}}$ at short interval which is correspondingly reflected in $\mathrm{E}_{1}$ curve also. Outside this interval, voltage variations are reflected in $E_{1}$ although $I_{d c}$ varies in perfect linear manner. 


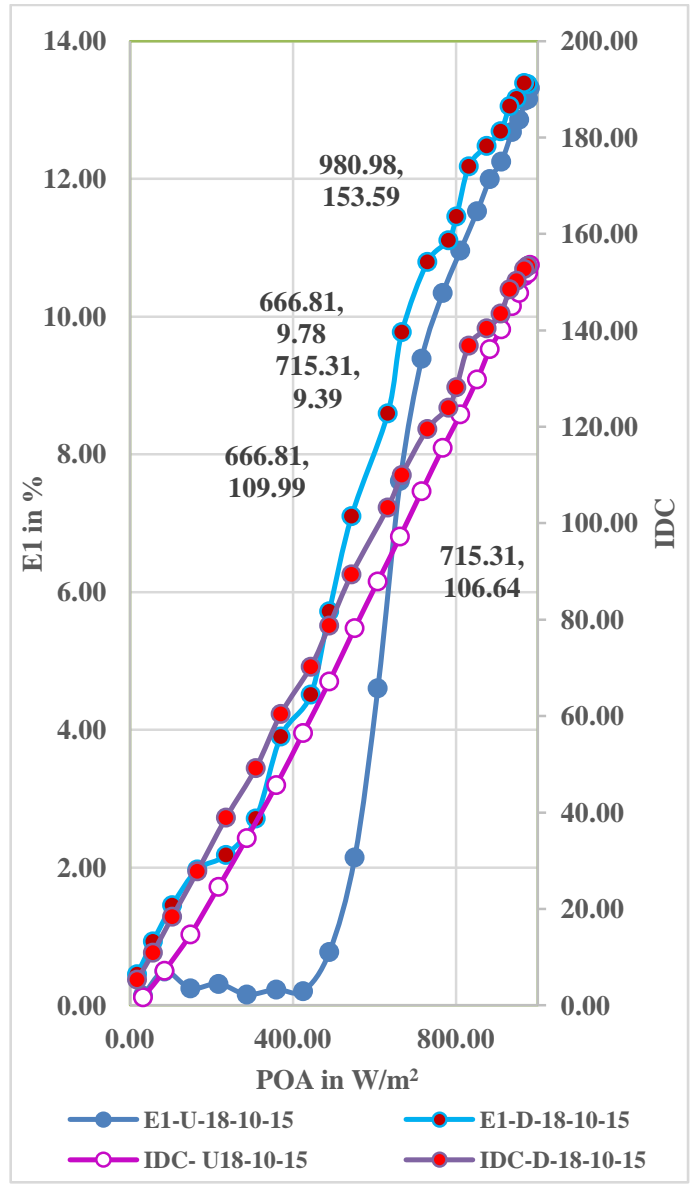

Figure 6: Variation of $E_{1}$ and $I_{d c}$ with respect to POA.

\subsection{Variation of Solar Cell Conversion \\ $\operatorname{Efficiency}\left(\mathbf{E}_{1}\right)$, DC Power $\operatorname{Efficiency}\left(\mathbf{E}_{2}\right)$, Cell Temperature and POA with Time for Winter Season}

The winter season extends from November to January with high POA for very short duration and low cell temperature. Variation of $E_{1}, V_{d c}$ and POA with time for $13^{\text {th }}$ November, $22^{\text {nd }}$ December 2015 and $8^{\text {th }}$ January 2016 are shown in figure 7, 9 and 12 respectively. Variation of $\mathrm{E}_{1}, \mathrm{E}_{2}$ and cell temperature with time for $13^{\text {th }}$ November, $22^{\text {nd }}$ December 2015 and $8^{\text {th }}$ January 2016 are shown in figure 8, 10 and 13 respectively. Variation of $E_{1}$ and $V_{d c}$ with respect to POA for $22^{\text {nd }}$ December 2015 are plotted in figure 11.

It can be observed that at lower cell temperature higher POA is required to attain high efficiency. On $13^{\text {th }}$ November $E_{1}$, and $E_{2}$ are only $1.75 \%$ and $10.31 \%$ respectively at $\mathrm{T}_{\mathrm{c}}$ equal to $39.36^{\circ} \mathrm{C}$ and POA equal to $632.90 \mathrm{~W} / \mathrm{m}^{2}$ attaining maximum value of $10.53 \%$ and $62.15 \%$ respectively for POA equal to 799.32 $\mathrm{W} / \mathrm{m}^{2}$ and $\mathrm{T}_{\mathrm{c}}$ equal to $47.80^{\circ} \mathrm{C}$ as shown vide figure 7 and 8 . $\mathrm{V}_{\mathrm{dc}}$ varies in accordance to POA for very short duration when $\mathrm{V}_{\mathrm{dc}}$ is nearly constant as shown vide figure 7 . Similar results are obtained for $22^{\text {nd }}$ December and $8^{\text {th }}$ January as shown vide figure 9-10 and 12-13 respectively showing very low efficiency at low temperature even at much higher POA. At low temperature $\mathrm{V}_{\mathrm{dc}}$ does not attain constant value and $\mathrm{E}_{1}$ curve follows $V_{d c}$ curve for the entire duration as shown vide figure 9 and 12 for $22^{\text {nd }}$ December and $8^{\text {th }}$ January respectively. This is further verified vide figure 11 for $22^{\text {nd }}$ December which shows $E_{1}$ varies in accordance to $V_{d c}$ for the entire duration.

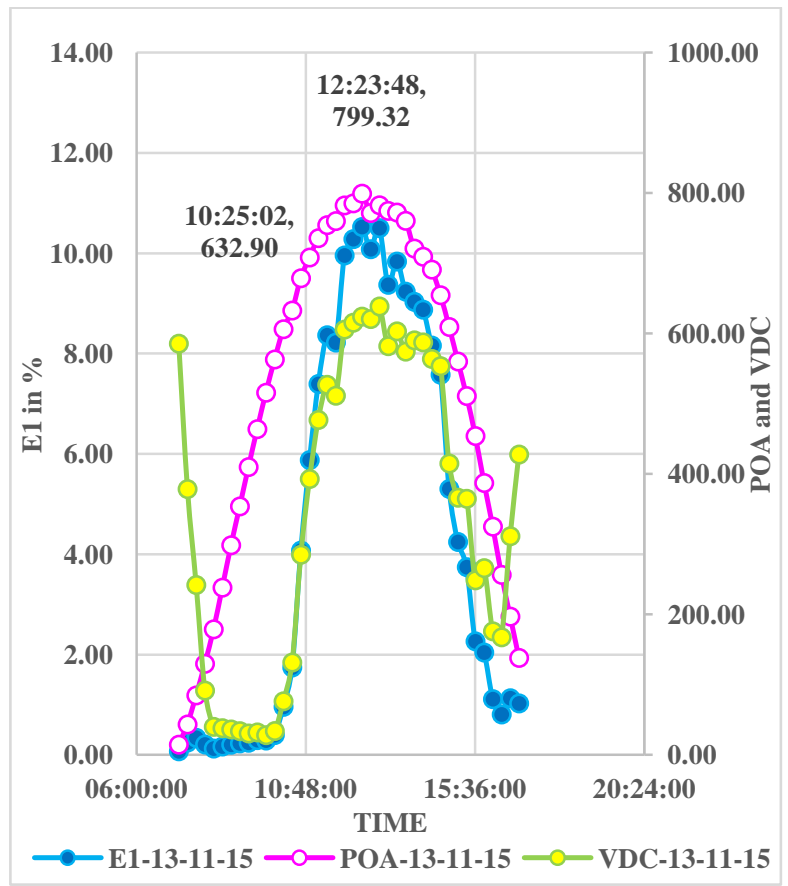

Figure 7: Variation of $E_{1}, V_{d c}$ and POA for $13^{\text {th }}$ November 2015.

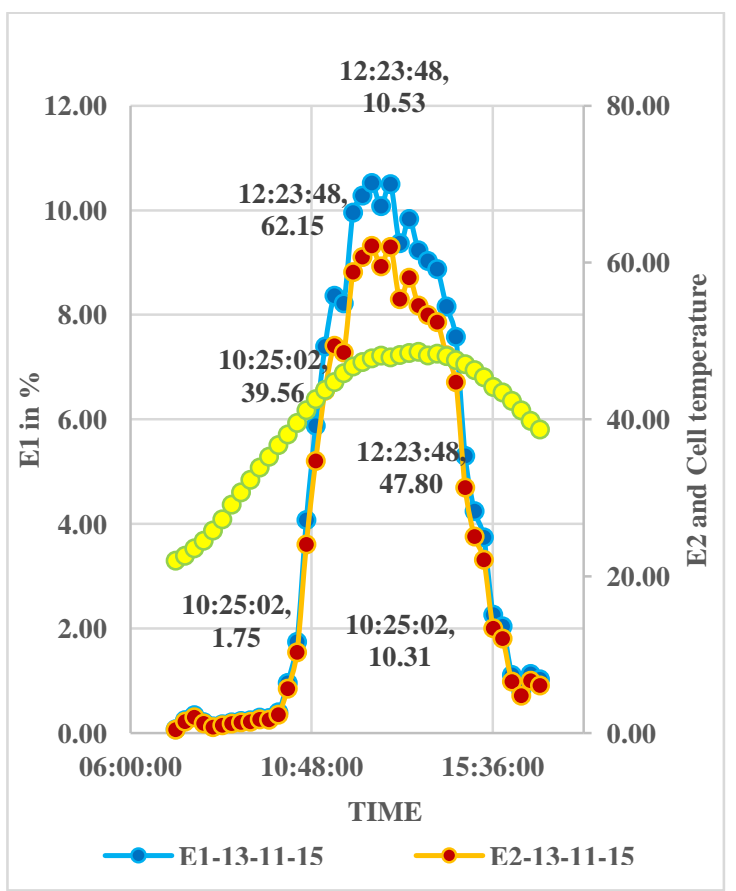

Figure 8: Variation of $E_{1}, E_{2}$ and cell temperature for $13^{\text {th }}$ November 2015. 


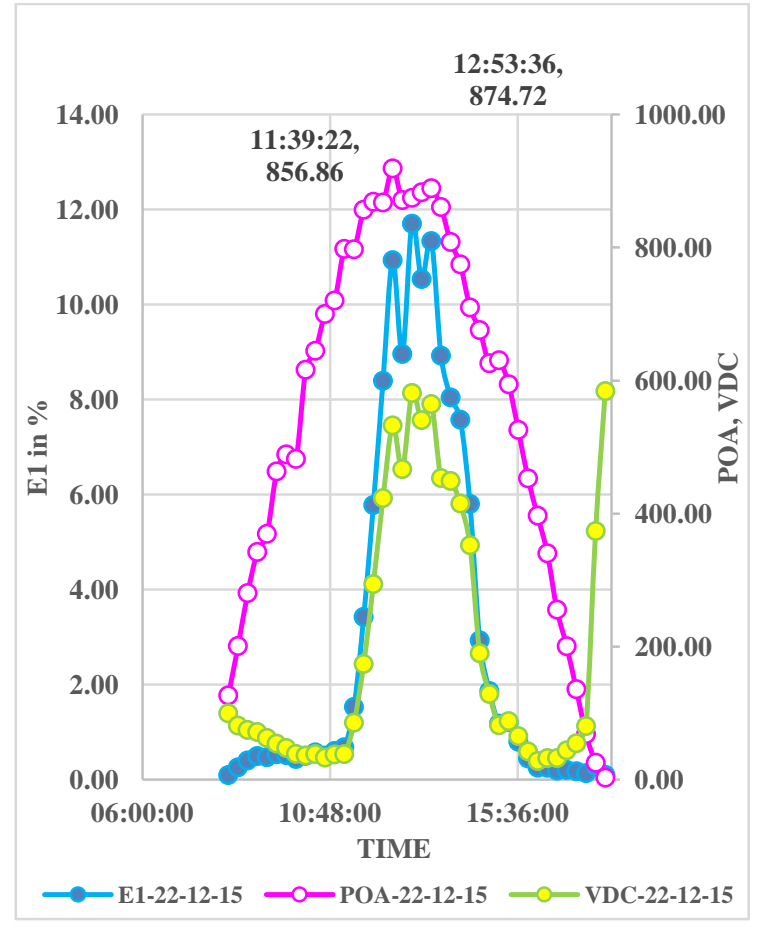

Figure 9: Variation of $E_{1}, V_{d c}$ and POA for $22^{\text {nd }}$ December 2015.

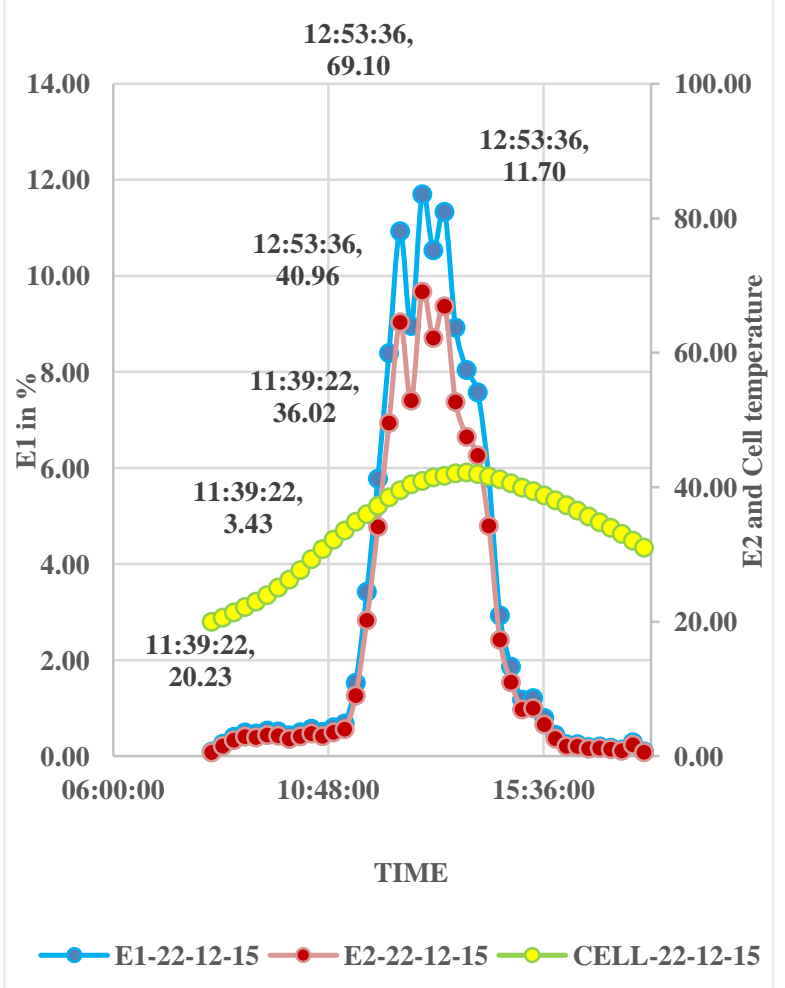

Figure 10: Variation of $E_{1}, E_{2}$ and cell temperature for $22^{\text {nd }}$ December 2015.

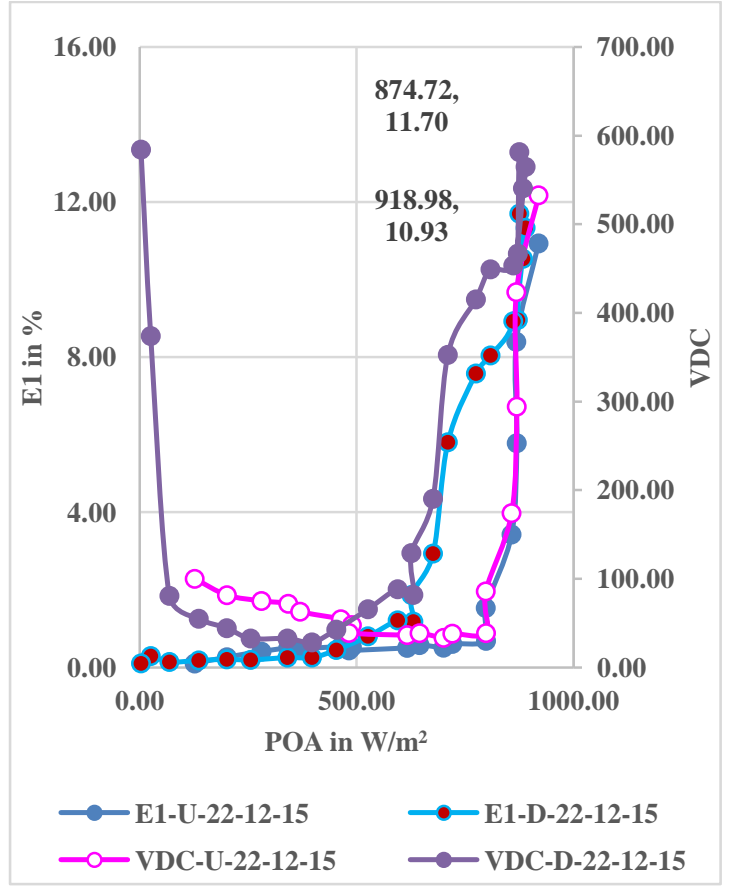

Figure 11: Variation of $E_{1}$ and $V_{d c}$ with respect to POA for $22^{\text {nd }}$ December 2015.

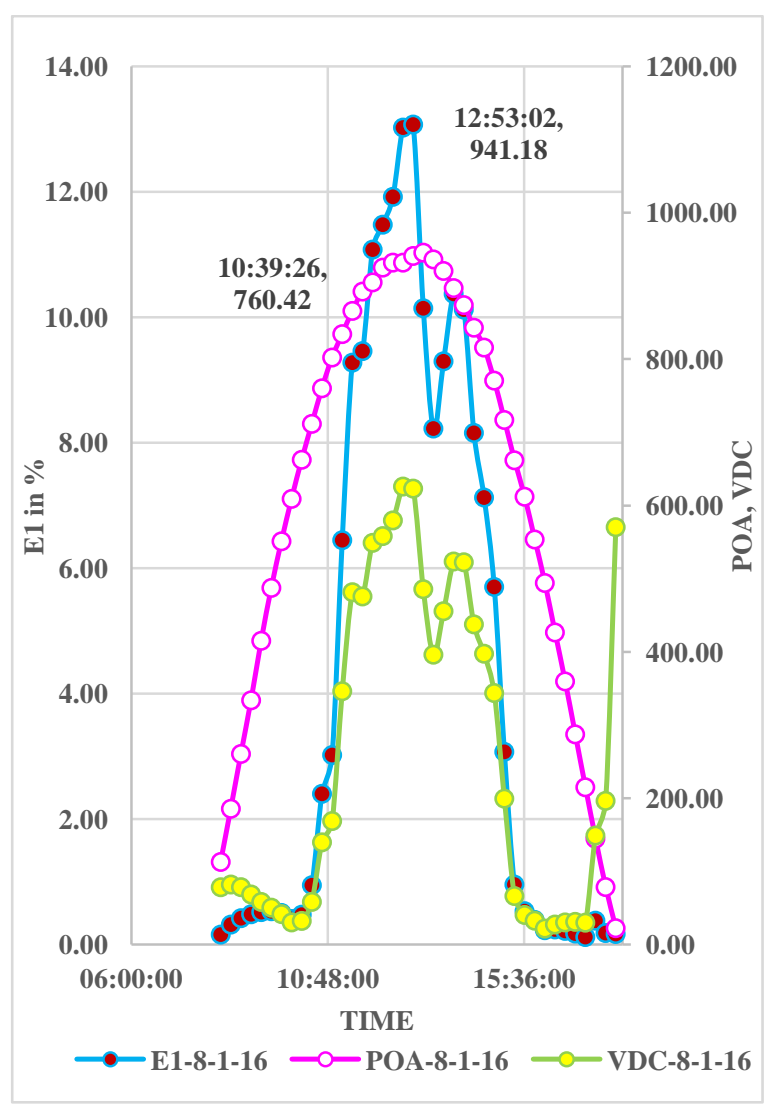

Figure 12: Variation of $E_{1}, V_{d c}$ and POA for $8^{\text {th }}$ January 2016. 


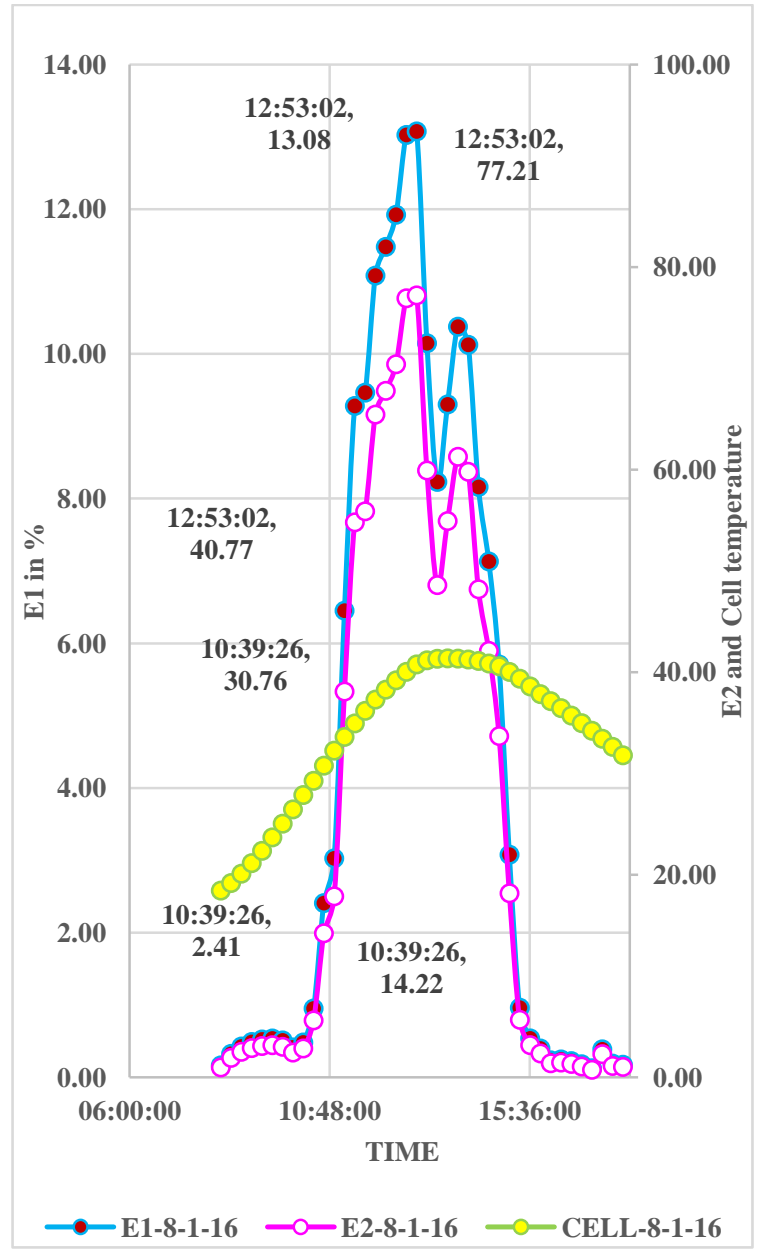

Figure 13: Variation of $E_{1}, E_{2}$ and cell temperature for $8^{\text {th }}$ January 2016.

\subsection{Variation of Solar Cell Conversion Efficiency (E1), DC Power Efficiency (E2), Cell Temperature and POA with Time for Spring Season}

The spring season with moderate cell temperature in $40-53^{\circ} \mathrm{C}$ range and high POA for reasonable duration extends from February to March. Variation of $\mathrm{E}_{1}, \mathrm{~V}_{\mathrm{dc}}$ and POA with time for $22^{\text {nd }}$ February and $8^{\text {th }}$ March are shown in figure 14 and 20 respectively. Variation of $E_{1}, E_{2}$ and cell temperature with time for $22^{\text {nd }}$ February and $8^{\text {th }}$ March are shown in figure 15 and 21 respectively. Variation of $\mathrm{E}_{1}, \mathrm{I}_{\mathrm{dc}}$ and cell temperature with respect to time is shown in figure 16. Variation of $E_{1}$ and $V_{d c}$, variation of $E_{1}$ and $I_{d c}$; variation of $I_{d c}$ and cell temperature with respect to POA for $22^{\text {nd }}$ February are shown in figure 17 , 18 and 19 respectively.

High efficiency with $E_{1}$ and $E_{2}$ as high as $15.16 \%$ and $89.54 \%$ respectively are obtained on $22^{\text {nd }}$ February at $\mathrm{T}_{\mathrm{c}}$ equal to $46.77^{\circ} \mathrm{C}$ and POA $991.34 \mathrm{~W} / \mathrm{m}^{2}$ while lower $\mathrm{E}_{1}$ and $\mathrm{E}_{2}$ equal to $13.63 \%$ and $80.46 \%$ are obtained at higher POA and lower $\mathrm{T}_{\mathrm{c}}$ that is $994.09 \mathrm{~W} / \mathrm{m}^{2}$ and $42.98^{\circ} \mathrm{C}$ respectively as shown vide figure 14 and 15 showing positive effect of cell temperature on efficiency, increasing with increasing cell temperature even though POA decreases. $\mathrm{E}_{1}, \mathrm{E}_{2}$ equal to $14.36 \%$ and $84.81 \%$ respectively are obtained on $8^{\text {th }}$ March at $\mathrm{T}_{\mathrm{c}}$ equal to $48.42^{\circ} \mathrm{C}$, POA equal to $984.92 \mathrm{~W} / \mathrm{m}^{2}$ with comparatively lower $\mathrm{E}_{1}$ that is
$13.86 \%$ at higher POA that is $989.64 \mathrm{~W} / \mathrm{m}^{2}$ and lower $\mathrm{T}_{\mathrm{c}}$ that is $44.13{ }^{\circ} \mathrm{C}$ shown vide figure 20 and 21 , due to positive effect of cell temperature for nearly constant POA. The positive effect of cell temperature is normally not visible as variations in POA are more significant compared to variations in cell temperature but for nearly constant POA for example on $22^{\text {nd }}$ February variations in cell temperature are far more significant compared to POA, the result is increase in $\mathrm{I}_{\mathrm{dc}}$ from $155.52 \mathrm{~A}$ to $168.34 \mathrm{~A}$ with corresponding increase in $\mathrm{E}_{1}$ from $13.63 \%$ to $15.16 \%$ as cell temperature increases from $42.98^{\circ} \mathrm{C}$ to $46.77^{\circ} \mathrm{C}$ as shown vide figure 16 although POA decreases from $994.09 \mathrm{~W} / \mathrm{m}^{2}$ to $991.34 \mathrm{~W} / \mathrm{m}^{2}$ as shown vide figure 14 and 17 , depicting positive effect of cell temperature on both $\mathrm{I}_{\mathrm{dc}}$ and $\mathrm{E}_{1}$.

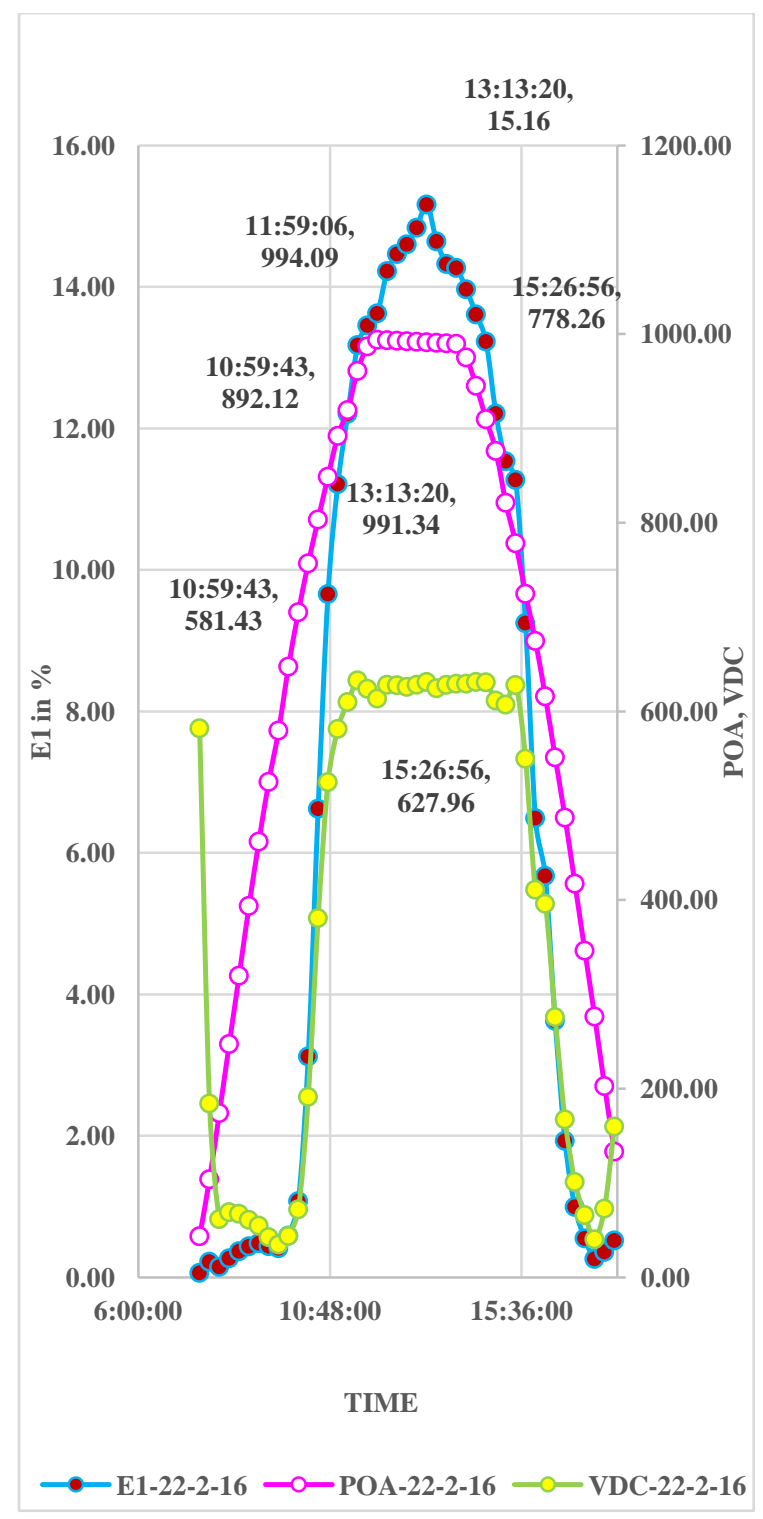

Figure 14: Variation of $E_{1}, V_{d c}$ and POA for $22^{\text {nd }}$ February 2016. 


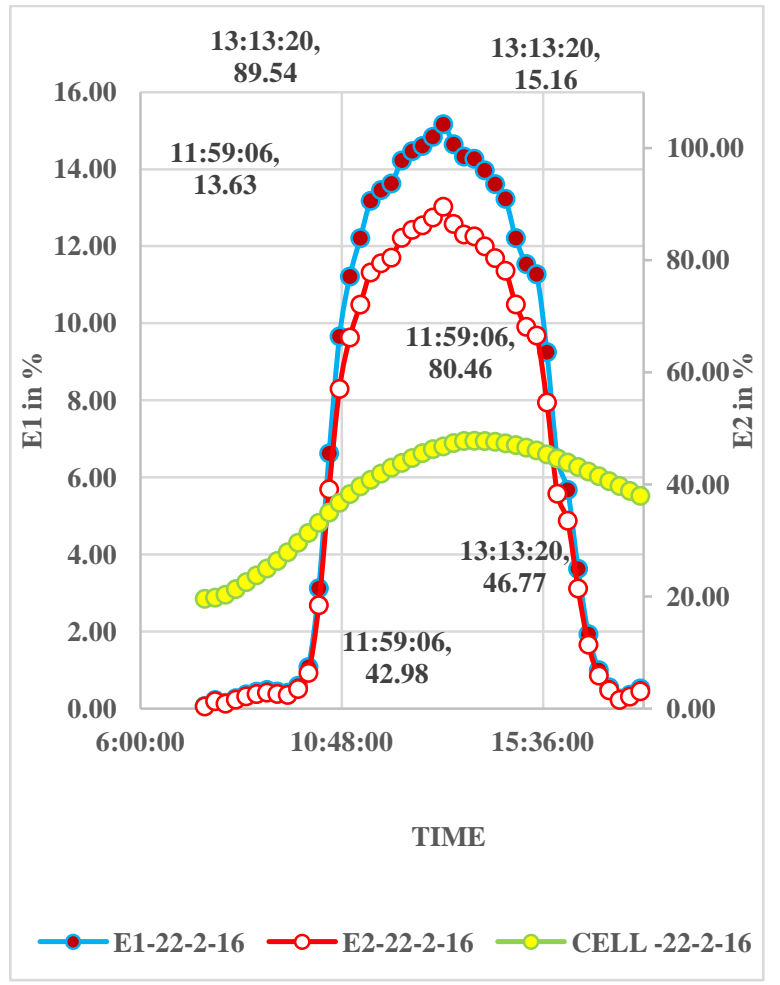

Figure 15: Variation of $E_{1}, E_{2}$ and cell temperature for $22^{\text {nd }}$ February 2015.

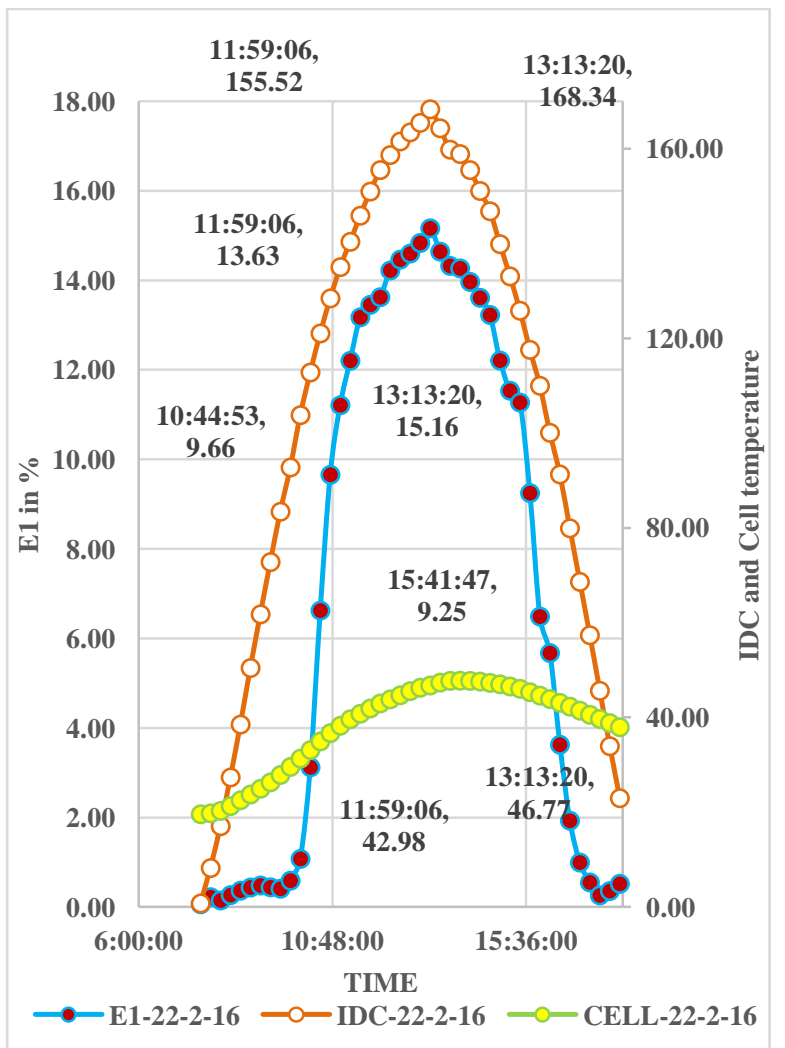

Figure 16: Variation of $E_{1}, I_{d c}$ and $T_{c}$ with respect to time for $22^{\text {nd }}$ February 2016.

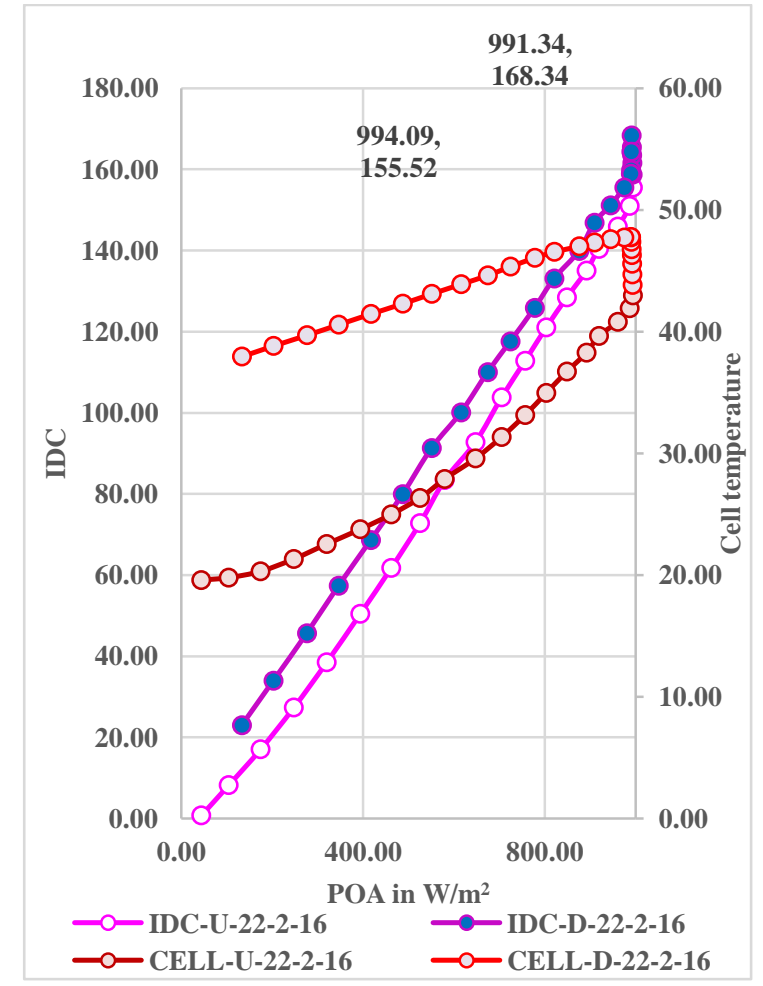

Figure 17: Variation of $I_{d c}$ and $T_{c}$ with respect to POA for $22^{\text {nd }}$ February 2016.

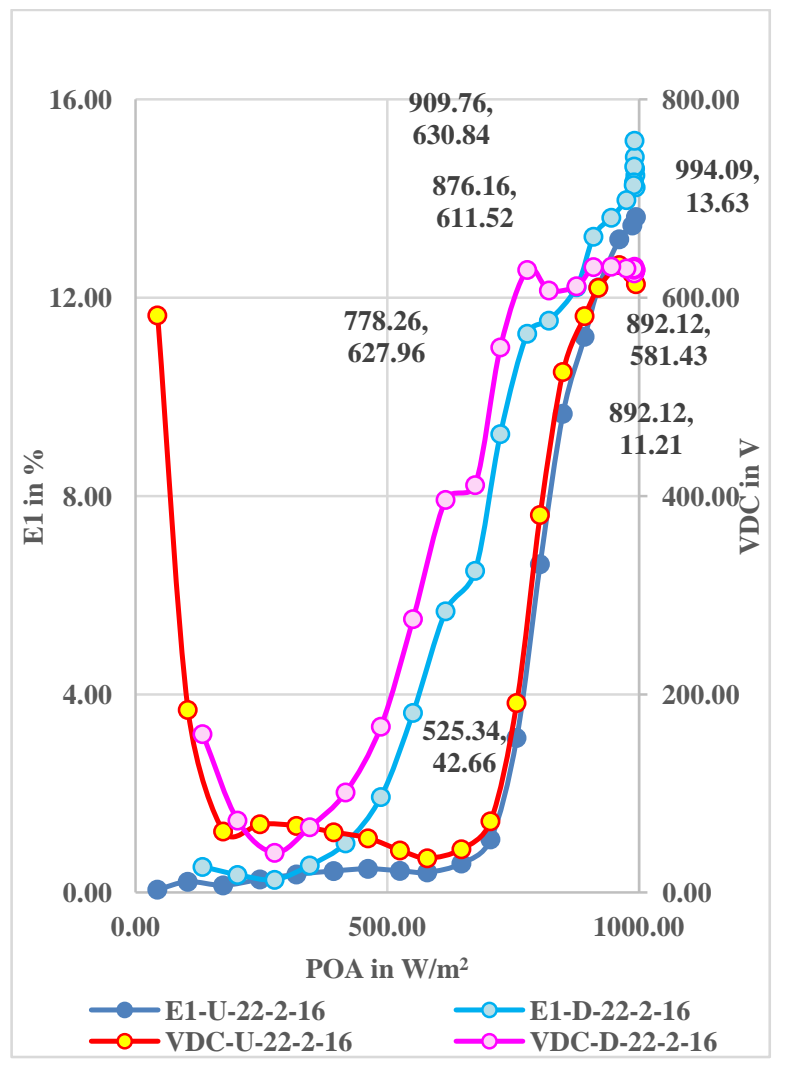

Figure 18: Variation of $E_{1}$, and $V_{d c}$ with respect to POA for $22^{\text {nd }}$ February 2016. 


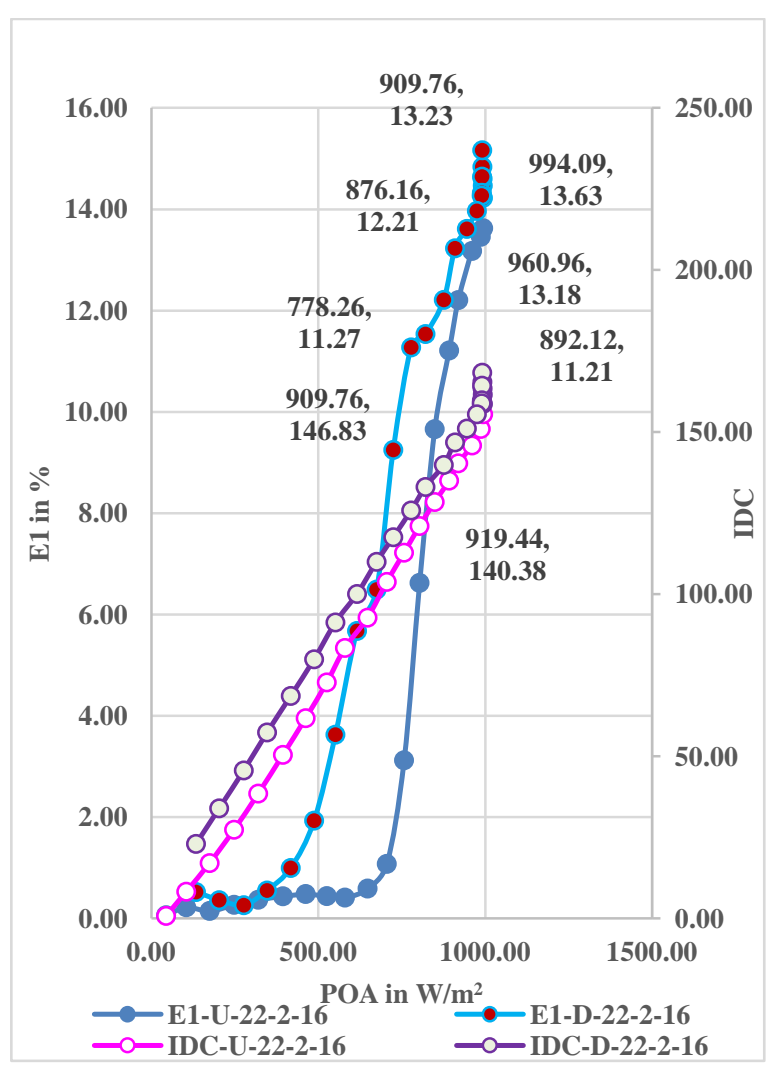

Figure 19: Variation of $E_{1}$, and $I_{d c}$ with respect to POA for $22^{\text {nd }}$ February 2016.

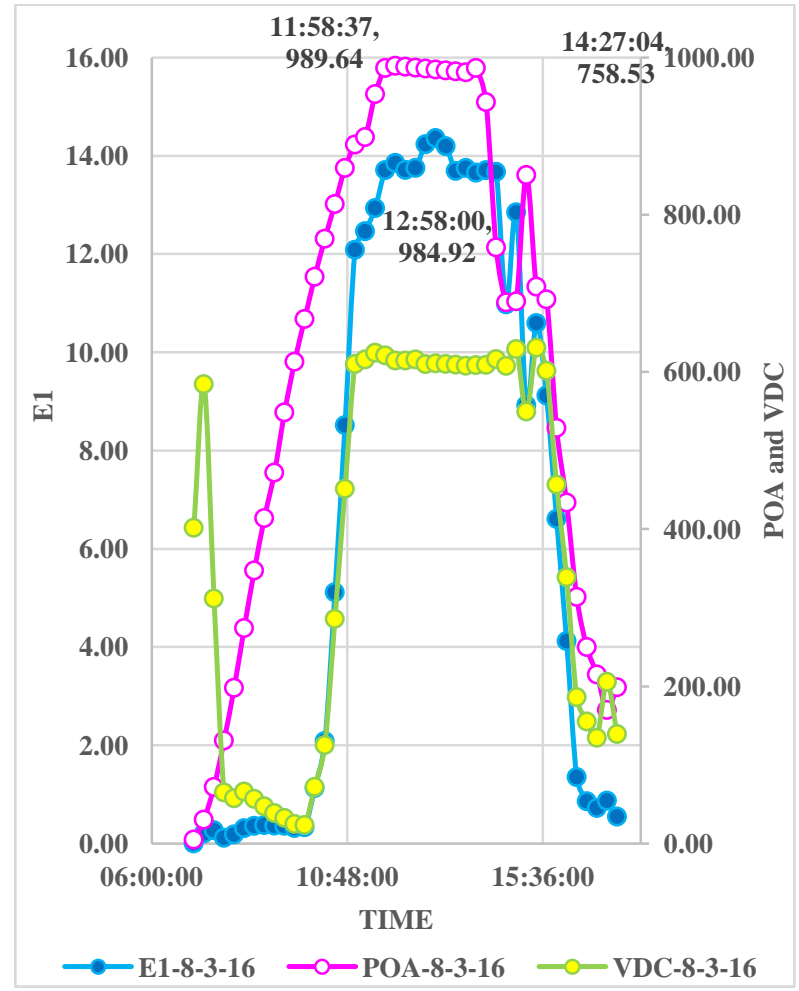

Figure 20: Variation of $E_{1}, V_{d c}$ and POA for $8^{\text {th }}$ March 2016.

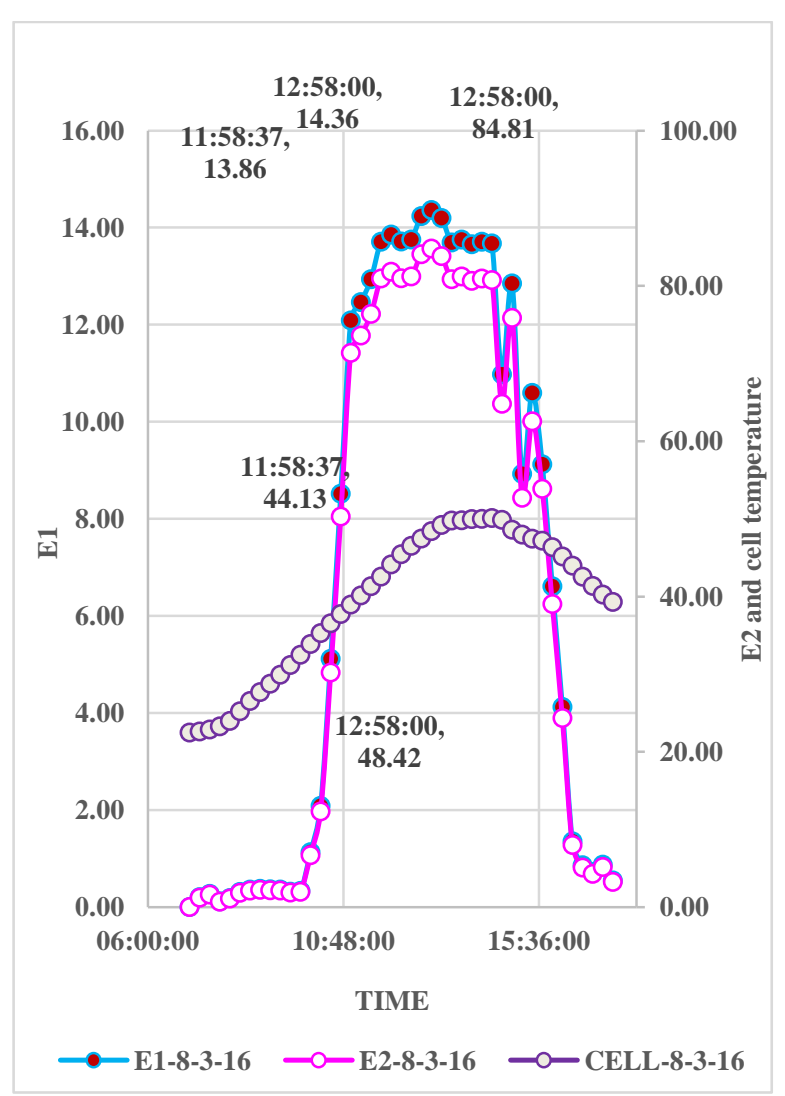

Figure 21: Variation of $E_{1}, E_{2}$ and cell temperature for $8^{\text {th }}$ March 2016.

$E_{1}$ and $E_{2}$ vary in accordance to $V_{d c}$ until $V_{d c}$ attains nearly constant value, thereafter it varies in accordance to $I_{d c}$ until $V_{d c}$ is nearly constant as shown vide figure 14 and 20 for $22^{\text {nd }}$ February and $8^{\text {th }}$ March respectively. This is further verified vide figure 18 and 19 for $22^{\text {nd }}$ February. $V_{d c}$ remains nearly constant in the time interval 10:59:43 to 15:26:56 with corresponding $\mathrm{V}_{\mathrm{dc}}$ value equal to $581.43 \mathrm{~V}$ and $627.96 \mathrm{~V}$ respectively and corresponding POA equal to $892.12 \mathrm{~W} / \mathrm{m}^{2}$ and $778.26 \mathrm{~W} / \mathrm{m}^{2}$ respectively as shown vide figure 14 . As POA increases right from very low value to $892.12 \mathrm{~W} / \mathrm{m}^{2}, \mathrm{E}_{1}$ varies according to $\mathrm{V}_{\mathrm{dc}}$ as shown vide figure 14 and 18 . With further increase in POA from $892.12 \mathrm{~W} / \mathrm{m}^{2}$ to $994.09 \mathrm{~W} / \mathrm{m}^{2}$ and then reducing back to 909.76 with descending sun, the $\mathrm{E}_{1}$ curve follows $I_{d c}$ as shown vide figure 19 thereafter although high $V_{d c}$ is maintained $\mathrm{V}_{\mathrm{dc}}$ reduces by about $1 \%$ of its maximum rated value that is from $630.84 \mathrm{~V}$ to $611.52 \mathrm{~V}$ as POA reduces from 909.76 to $876.16 \mathrm{~W} / \mathrm{m}^{2}$, the result is that although $\mathrm{I}_{\mathrm{dc}}$ decreases linearly, $\mathrm{E}_{1}$ shows variation in gradient reflecting effect of voltage variations. Thus, for any two consecutive points if voltage variation is less than $1 \%$ of its rated value $\mathrm{E}_{1}$ follows $\mathrm{I}_{\mathrm{dc}}$ curve in perfect linear manner but voltage variation greater than $1 \%$ are reflected in $\mathrm{E}_{1}$ and correspondingly $\mathrm{E}_{2}$ curve showing significant effect of voltage variations in comparision to current variations. 


\subsection{Variation of Solar Cell Conversion Efficiency(E1), DC Power Efficiency(E2), Cell Temperature and POA with Time for Summer Season}

The rainy season may extend from June to August but the days considered for analysis, $4^{\text {th }}$ June and $11^{\text {th }}$ July represents clear sunny day and so have been considered in summer season. Variation of $\mathrm{E}_{1}, \mathrm{~V}_{\mathrm{dc}}$ and POA with time for $12^{\text {th }}$ April, $13^{\text {th }}$ May, $4^{\text {th }}$ June and $11^{\text {th }}$ July are shown in figure 22, 24, 26 and 30 respectively. Variation of $E_{1}, E_{2}$ and cell temperature with time for $12^{\text {th }}$ April, $13^{\text {th }}$ May, $4^{\text {th }}$ June and $11^{\text {th }}$ July are shown in figure 23, 25, 27 and 31 respectively. Variation of $E_{1}$ and $\mathrm{V}_{\mathrm{dc}}$, variation of $\mathrm{E}_{1}$ and $\mathrm{I}_{\mathrm{dc}}$ with POA for $4^{\text {th }}$ June are shown in figure 28 and 29 respectively.

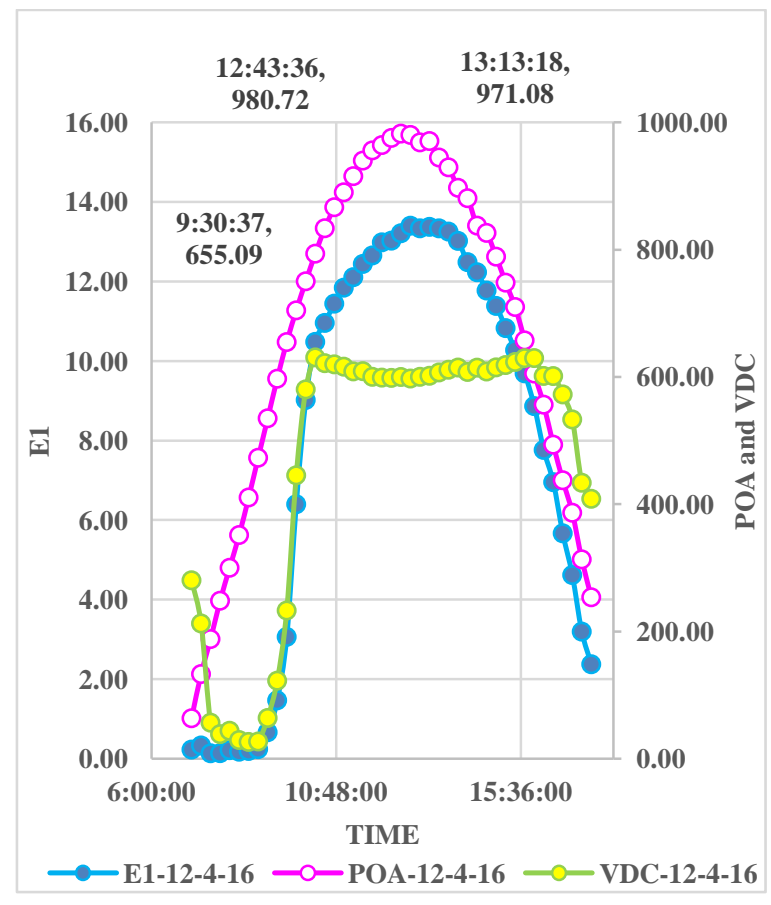

Figure 22: Variation of $E_{1}, V_{d c}, P O A$ and cell temperature for $12^{\text {th }}$ April 2016.

In summers both $E_{1}$ and $E_{2}$ increase with increase in POA and increase in cell temperature even as cell temperature increases up to $58.92^{\circ} \mathrm{C}$. On $12^{\text {th }}$ April $\mathrm{E}_{1}$ increases from $3.07 \%$ to $13.41 \%, \mathrm{E}_{2}$ increases from $18.10 \%$ to $79.17 \%$ as $\mathrm{T}_{\mathrm{c}}$ increases from $39.91{ }^{\circ} \mathrm{C}$ to $54.90{ }^{\circ} \mathrm{C}$ and POA increases from 655.09 $\mathrm{W} / \mathrm{m}^{2}$ to $980.72 \mathrm{~W} / \mathrm{m}^{2}$ shown vide figure 22 and 23 . On $13^{\text {th }}$ May maximum $\mathrm{E}_{1}$ and $\mathrm{E}_{2}$ with values $12.61 \%$ and $72.27 \%$ respectively are obtained at cell temperature as high as $58.92^{\circ} \mathrm{C}$ and POA equal to $914.23 \mathrm{~W} / \mathrm{m}^{2}$ shown vide figure 24 and 25 . At maximum $\mathrm{T}_{\mathrm{c}}$ of $61{ }^{\circ} \mathrm{C}, \mathrm{E}_{1}$ and $\mathrm{E}_{2}$ reduce slightly to $12.24 \%$ and $72.27 \%$. On $4^{\text {th }}$ June maximum $\mathrm{E}_{1}$ and $\mathrm{E}_{2}$ with values $13.51 \%$ and $79.77 \%$ respectively are obtained at cell temperature as high as $58.14^{\circ} \mathrm{C}$ and POA $989.68 \mathrm{~W} / \mathrm{m}^{2}$ shown vide figure 26 and $27 . \mathrm{E}_{1}$ and $\mathrm{E}_{2}$ with values $12.82 \%$ and $75.70 \%$ respectively are obtained at maximum cell temperature of $61.28^{\circ} \mathrm{C}$, that is remarkably high values of $\mathrm{E}_{1}$ and $\mathrm{E}_{2}$ at high cell temperature. On $11^{\text {th }}$ July maximum values for $\mathrm{E}_{1}$ and $\mathrm{E}_{2}$ are $12.75 \%$ and $75.31 \%$ respectively at POA $896.15 \mathrm{~W} / \mathrm{m}^{2}$ and $\mathrm{T}_{\mathrm{c}} 54.25^{\circ} \mathrm{C}$ depicted vide figure 30 and 31 , showing remarkably high efficiency at high cell temperature.

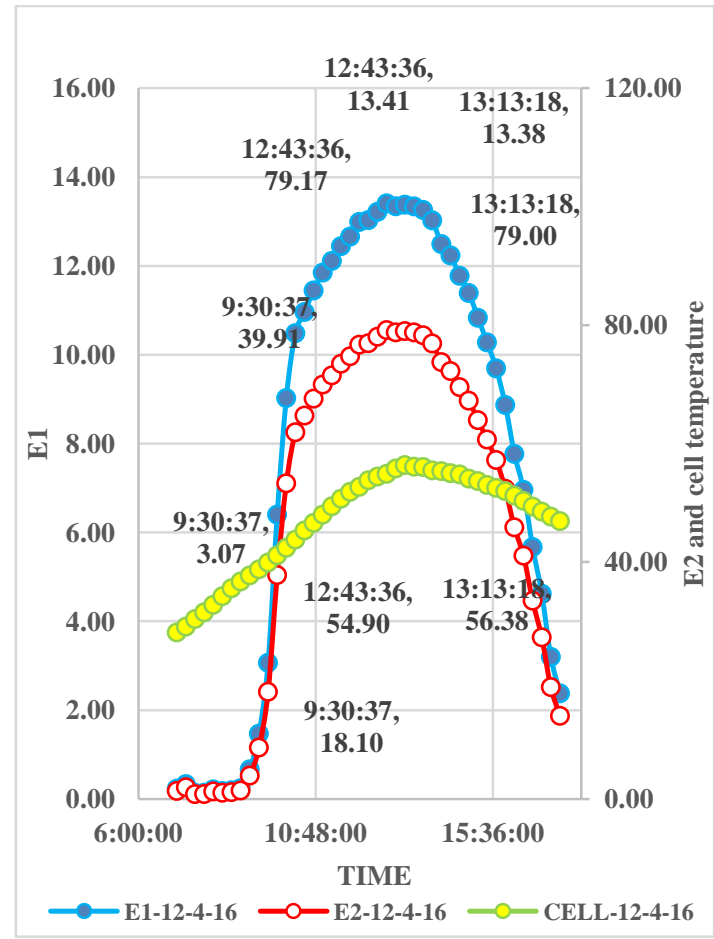

Figure 23: Variation of $E_{1}, E_{2}$ and cell temperature for $12^{\text {th }}$ April 2016.

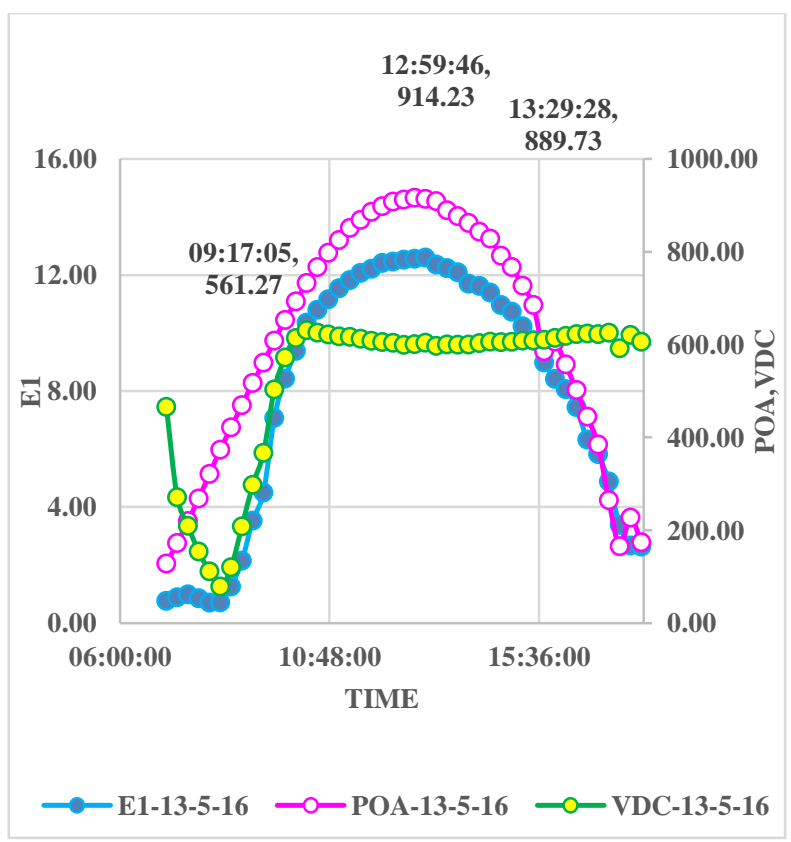

Figure 24: Variation of $E_{1}, V_{d c}$ and POA cell temperature for $13^{\text {th }}$ May 2016. 


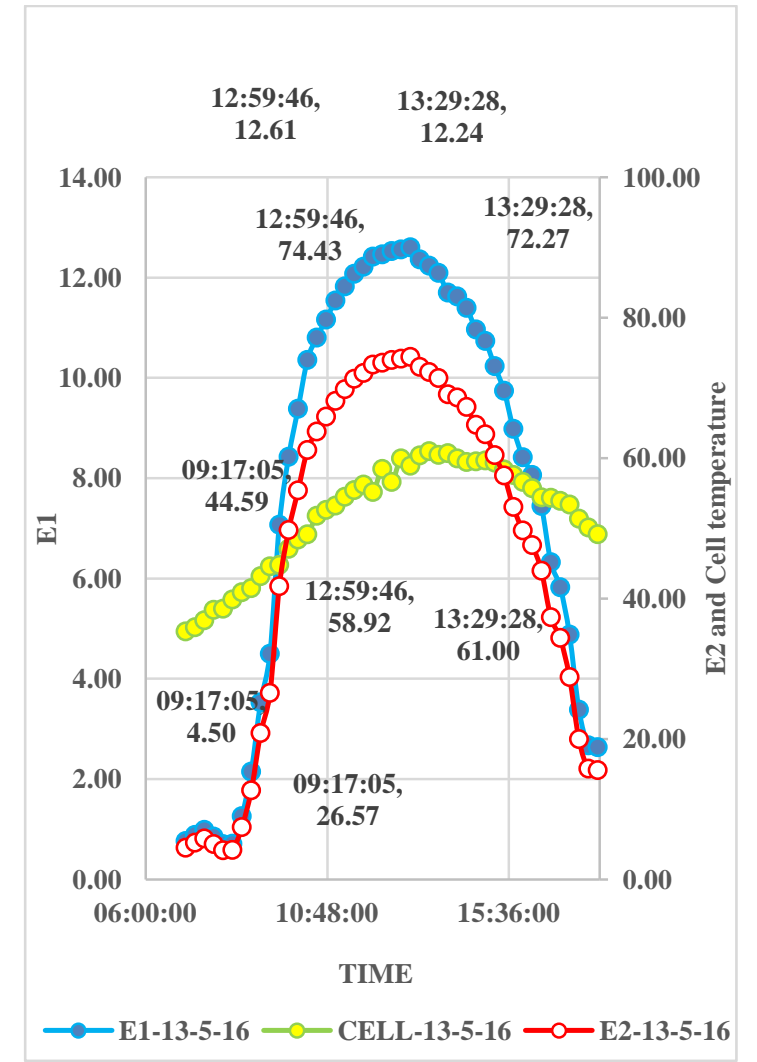

Figure 25: Variation of $E_{1}, E_{2}$ and cell temperature for $13^{\text {th }}$ May 2016.

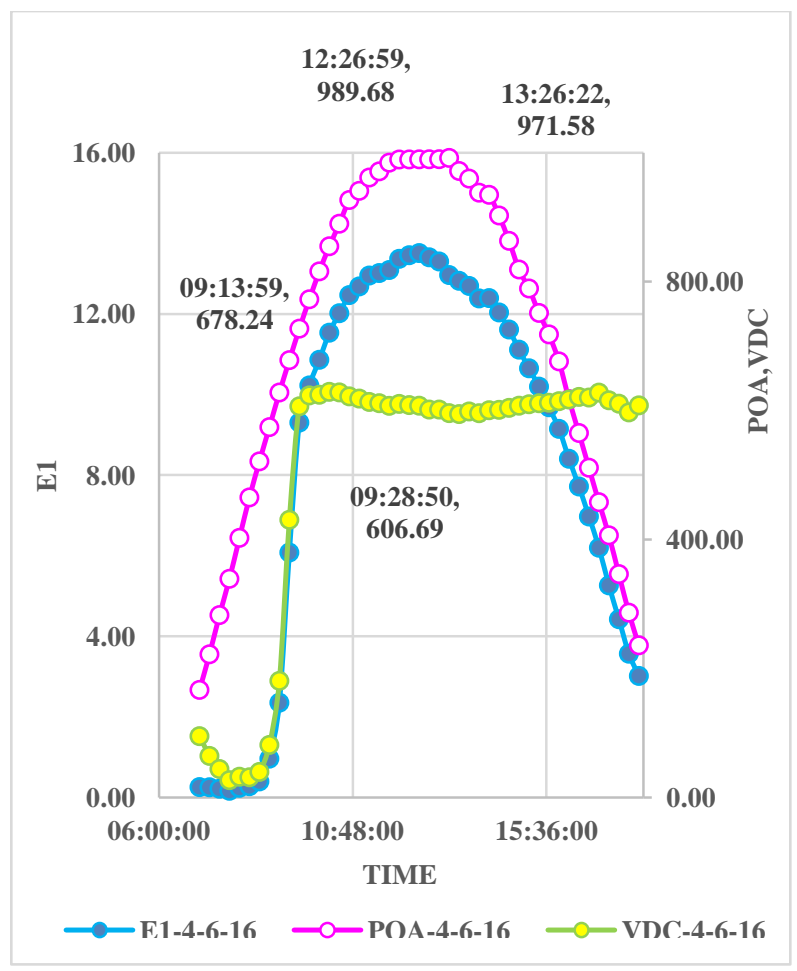

Figure 26: Variation of $E_{1}, V_{d c}$ and POA cell temperature for $4^{\text {th }}$ June 2016.

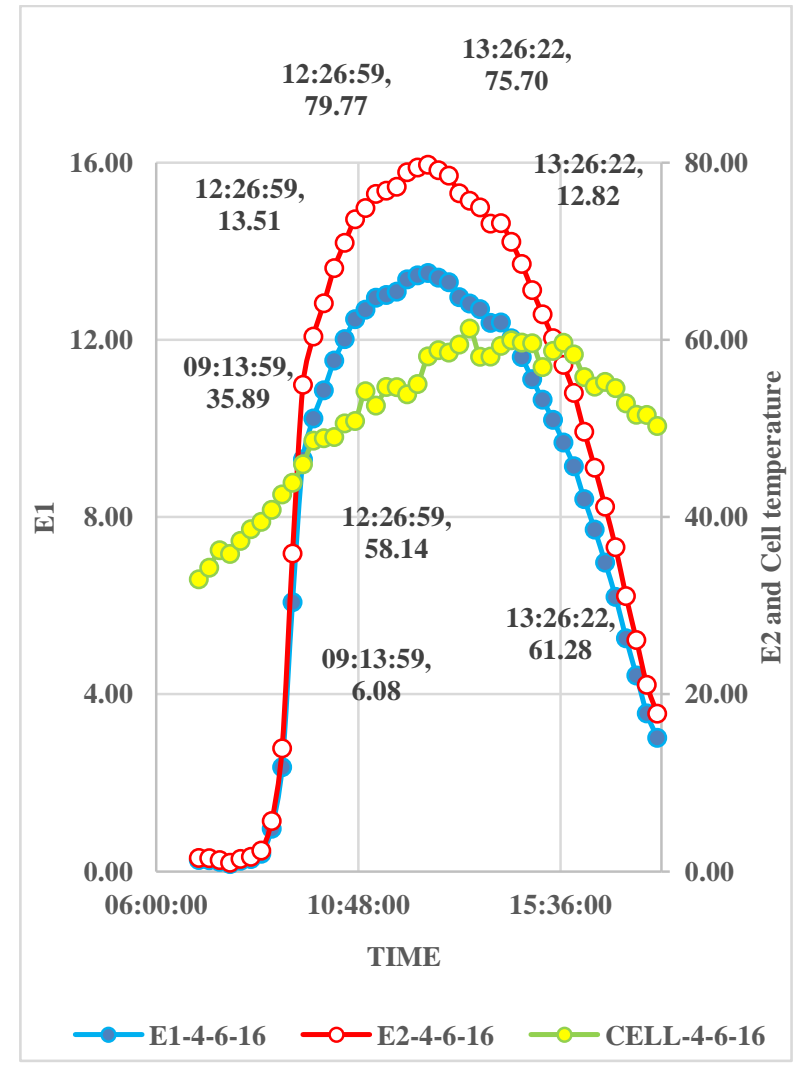

Figure 27: Variation of $E_{1}, E_{2}$ and cell temperature for $4^{\text {th }}$ June 2016.

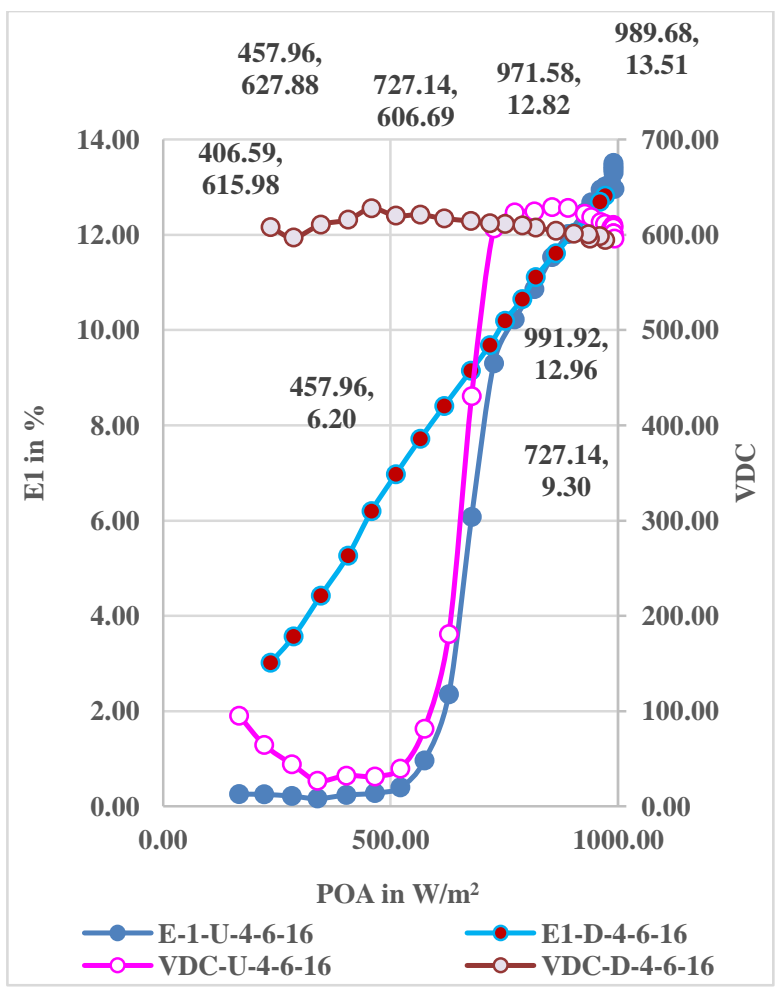

Figure 28: Variation of $E_{1}$ and $V_{d c}$ with POA for $4^{\text {th }}$ June 2016. 


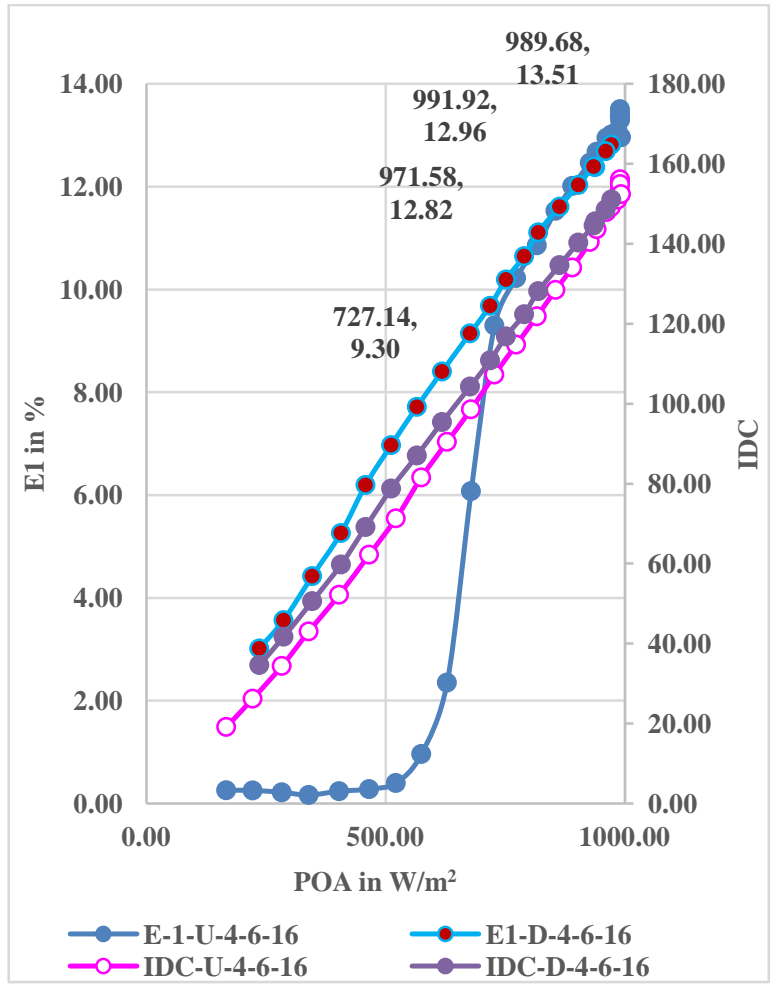

Figure 29: Variation of $E_{1}$ and $I_{d c}$ with POA for $4^{\text {th }}$ June 2016.

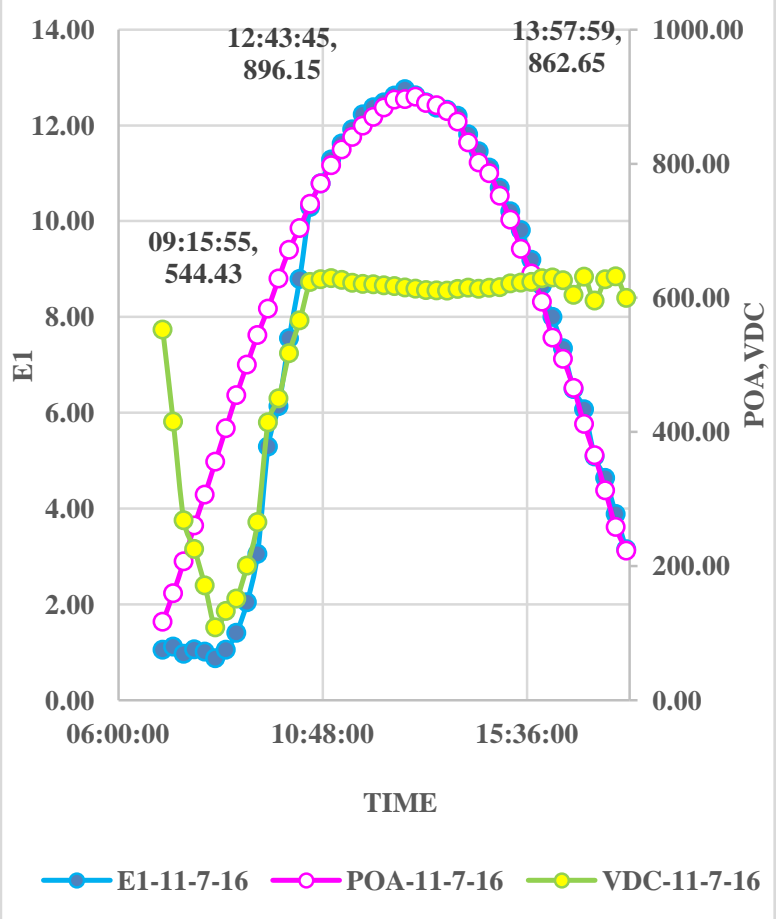

Figure 30: Variation of $E_{1}, V_{d c}, P O A$ and cell temperature for $11^{\text {th }}$ July 2016.

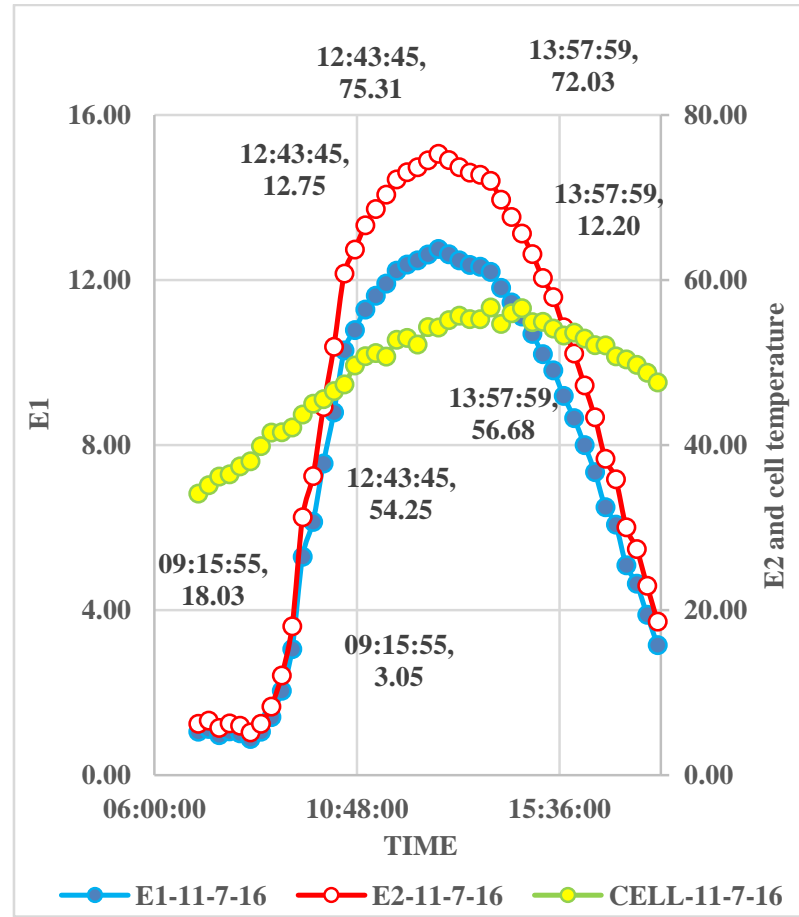

Figure 31: Variation of $E_{1}, E_{2}$ and cell temperature for $11^{\text {th }}$ July 2016.

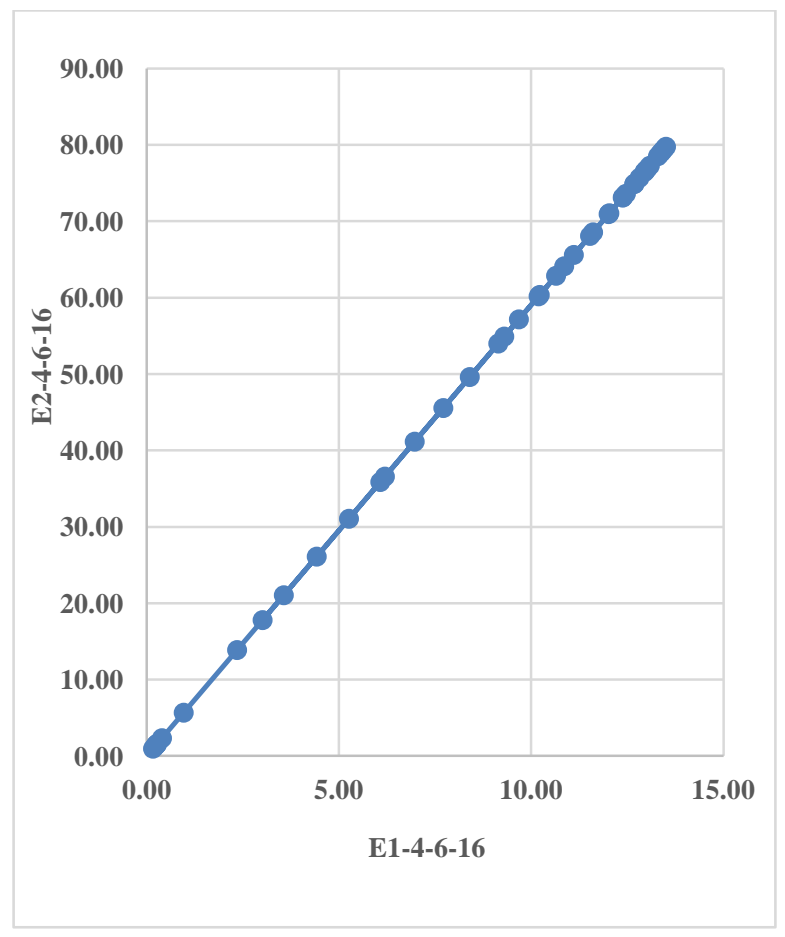

Figure 32: Variation of $E_{2}$ with respect to $E_{1}$ for $4^{\text {th }}$ June.

High $\mathrm{V}_{\mathrm{dc}}$ is obtained only at high cell temperature as mentioned by Garg and JB [14] and is also visible from figures $1,3,5,7,9,12,14,18,20,22,24,26,28$ and 30 but has not been elaborated in this paper. Until $\mathrm{V}_{\mathrm{dc}}$ attains nearly constant value both $E_{1}$ and $E_{2}$ vary in accordance to voltage as shown vide figure $22,24,26$ and 30 for $12^{\text {th }}$ April, $13^{\text {th }}$ May, $4^{\text {th }}$ June and $11^{\text {th }}$ July respectively for $E_{1}$ only but holds true for $E_{2}$ also as there is perfect linear relationship between $E_{1}$ and $E_{2}$ shown only for $4^{\text {th }}$ June vide figure 32 but is true for all dates. At high 
cell temperature $\mathrm{V}_{\mathrm{dc}}$ becomes independent of POA and remains constant for entire duration as shown vide figure 24, 26 and 30 for $13^{\text {th }}$ May, $4^{\text {th }}$ June and $11^{\text {th }}$ July respectively.

Once $V_{\mathrm{dc}}$ attains constant value $\mathrm{E}_{1}$ and $\mathrm{E}_{2}$ vary in accordance to POA and $\mathrm{I}_{\mathrm{dc}}$. The fact can be further explained for $4^{\text {th }}$ June vide figure 28 and $29 . \mathrm{V}_{\mathrm{dc}}$ attains $606.69 \mathrm{~V}$ at 9:28:50 and POA equal to $727.14 \mathrm{~W} / \mathrm{m}^{2}$, thereafter it continues to maintain nearly constant value irrespective of POA as shown vide figure 28 and 29. As POA increases from $727.14 \mathrm{~W} / \mathrm{m}^{2}$ to $991.92 \mathrm{~W} / \mathrm{m}^{2}$, reducing back to $457.96 \mathrm{~W} / \mathrm{m}^{2}$ with descending sun, $\mathrm{E}_{1}$ and correspondingly $\mathrm{E}_{2}$ varies linearly with $\mathrm{I}_{\mathrm{dc}}$. For voltage variation greater than $1 \%$ between two consecutive points slight change in gradient of $E_{1}$ is observed as can be seen when $\mathrm{V}_{\mathrm{dc}}$ reduces from $627.88 \mathrm{~V}$ to $615.98 \mathrm{~V}$ showing that for $\mathrm{E}_{1}$ and $\mathrm{E}_{2}$ even $1 \%$ of voltage variations are more prominent compared to current variations.

To evaluate relative effect of POA and $\mathrm{T}_{\mathrm{c}}$ over the day average efficiency $\left(\mathrm{E}_{1}\right.$ and $\left.\mathrm{E}_{2}\right)$, average cell temperature, average POA

Table 2 Average Efficiency, Energy Yield and Maximum Efficiency of the Day

\begin{tabular}{|c|c|c|c|c|c|c|c|c|}
\hline Day & $\mathrm{E}_{1 \max }$ in $\%$ & $\mathrm{E}_{\text {lav }}$ in $\%$ & $\mathrm{E}_{2 \max }$ in $\%$ & $\mathrm{E}_{2 \mathrm{av}}$ in $\%$ & $\mathrm{~T}_{\text {cav }}$ in ${ }^{\circ} \mathrm{C}$ & $\begin{array}{c}\mathrm{POA}_{\mathrm{av}} \text { in } \\
\mathrm{W} / \mathrm{m}^{2}\end{array}$ & $\begin{array}{c}\mathrm{P}_{\mathrm{dcav}} \text { in } \\
\mathrm{kW}\end{array}$ & $\begin{array}{c}\mathrm{P}_{\mathrm{dc}} \text { in } \\
\mathrm{kWh} / \text { day }\end{array}$ \\
\hline $11-09-15$ & 12.62 & 7.10 & 74.49 & 41.94 & 48.49 & 622.20 & 49.78 & 2240.11 \\
\hline $18-10-15$ & 13.32 & 7.44 & 79.07 & 43.93 & 47.53 & 608.22 & 52.14 & 2346.28 \\
\hline $13-11-15$ & 10.53 & 4.37 & 62.15 & 25.78 & 40.10 & 515.49 & 30.60 & 1224.02 \\
\hline $22-12-15$ & 11.70 & 2.98 & 69.10 & 17.58 & 34.20 & 553.77 & 20.87 & 834.78 \\
\hline $08-01-16$ & 13.08 & 4.30 & 77.21 & 25.38 & 33.95 & 617.62 & 30.12 & 1204.86 \\
\hline $22-02-16$ & 15.16 & 7.20 & 89.54 & 42.52 & 38.28 & 675.23 & 50.46 & 2169.86 \\
\hline 08-03-16 & 14.55 & 7.40 & 85.92 & 43.71 & 42.62 & 627.45 & 51.88 & 2334.64 \\
\hline $12-04-16$ & 13.41 & 7.94 & 79.17 & 46.88 & 46.84 & 668.08 & 55.64 & 2420.26 \\
\hline $13-05-16$ & 12.61 & 7.90 & 74.43 & 46.66 & 51.85 & 617.50 & 55.37 & 2491.84 \\
\hline 04-06-16 & 13.51 & 8.44 & 79.77 & 49.81 & 51.38 & 707.07 & 59.12 & 2660.44 \\
\hline $11-07-16$ & 12.75 & 7.76 & 75.31 & 45.84 & 48.89 & 612.55 & 54.41 & 2448.53 \\
\hline
\end{tabular}




\section{RESULTS}

- Maximum solar cell conversion efficiency of $15.16 \%$ is obtained at moderate cell temperature and very high POA in February but due to comparatively lower temperature average efficiency over the day is only $7.20 \%$ while in June although maximum $\mathrm{E}_{1}$ is only $13.51 \%$ but as average POA and average temperature are maximum and correspondingly the average efficiency and energy yield are also maximum with values $8.44 \%$ and 2660.44 $\mathrm{kWh} /$ day respectively.

- At high cell temperature in the month of May and June when the temperature is as high as $62^{\circ} \mathrm{C}$ and the average temperature is around $51-52^{\circ} \mathrm{C}, \mathrm{V}_{\mathrm{dc}}$ becomes independent of POA and nearly constant and high $\mathrm{V}_{\mathrm{dc}}$ is obtained for longer duration leading to higher energy yield.

- The average efficiencies in winters are extremely low with average value of $E_{1}$ varying between 3 to $4.4 \%$ and average value of $E_{2}$ varying between 17 to $26 \%$. In the month of December when average POA and cell temperature are minimum, the average $\mathrm{E}_{1}$ and $\mathrm{E}_{2}$ are minimum with corresponding values $2.98 \%$ and $17.58 \%$ respectively. The energy yield is also minimum in December.

- For spring season, the average cell temperature varies between $39-43^{\circ} \mathrm{C}$ with average $\mathrm{E}_{1}$ and $\mathrm{E}_{2}$ varying between 7.20 to $7.40 \%$ and $42.52 \%$ to $43.71 \%$ respectively.

- The average $E_{1}$ in post monsoon season varies between 7.10 to $7.44 \%$ and $E_{2}$ varies between 41.94 to $43.93 \%$. the energy yield is more compared to spring season due to slightly higher temperature.

The above analysis shows that both $\mathrm{E}_{1}$ and $\mathrm{E}_{2}$ increase with increase in POA and increase in cell temperature even as cell temperature increases up to $58.92^{\circ} \mathrm{C}$. The slight decrease in efficiency with decreasing POA and increasing temperature for short duration is insignificant. Higher efficiency is obtained at higher POA but much higher POA is required to attain same efficiency for cell temperature less than about $49^{\circ} \mathrm{C}$.

Variations in $E_{1}$ and correspondingly $E_{2}$ shown only for $E_{1}$ in figure $1,3,5,7,9,11,12,14,18,1920,22,24,26,28,29$ and 30 follow variations in $\mathrm{V}_{\mathrm{dc}}$ until $\mathrm{V}_{\mathrm{dc}}$ attains nearly constant high value thereafter it follows POA curve and consequently $\mathrm{I}_{\mathrm{dc}}$ as $I_{d c}$ varies linearly with POA clearly illustrating variations in $\mathrm{V}_{\mathrm{dc}}$ are more significant compared to variations in current. This is in accordance to the theoretical fact as DC power is product of DC voltage and DC current and as the maximum DC voltage of the array is $735.36 \mathrm{~V}$ while maximum DC current of the array is only $161.4 \mathrm{~A}$, consequently weightage of $\mathrm{V}_{\mathrm{dc}}$ is much more compared to weightage of current. As voltage variations are governed by cell temperature and current variations are governed by irradiance, it is the cell temperature that governs the efficiency and corresponding energy yield, signifying the defining positive role of high cell temperature.

\section{CONCLUSION}

In contrast to literature and research papers $[1,2,3,4,5,6,7,8,9,10]$ all which shows DC power efficiency and solar cell conversion efficiency decrease with increase in cell temperature above $25^{\circ} \mathrm{C}$, this paper brings forward for the first time ever the defining positive role of high cell temperature on DC power efficiency and solar cell conversion efficiency. High efficiency is obtained only at high temperature, further efficiency variations are governed by voltage variations and as voltage variations are governed by cell temperature it is the cell temperature that plays the defining positive role on both $\mathrm{E}_{1}$ and $E_{2}$. As further work simultaneous effect of cell temperature and irradiance on efficiency and energy yield for several days, for different types of solar PV module and for various locations of the world need to be done.

\section{ACKNOWLEDGMENT}

The authors would like to acknowledge the support of Shri J. K. Borgohain, Executive Director, Rajasthan Project. Oil India Lmt., Jodhpur, Shri D. C. Gogoi, Head, Technical Service, Oil India Lmt, Jodhpur; Shri Rajesh Kundoo, Incharge, PV Power Plant at Ramgarh, Jaisalmer in conducting this study.

\section{REFERENCES}

[1] Masters, G. M. "Renewable and efficient electric power systems". Wiley Interscience. 2004.

[2] Elminir, H.K. Benda,V. Tousek, J. "Effects of solar irradiation conditions and other factors on the outdoor performance of photovoltaic modules". Journal of electrical engineering, Vol. 52, No. 5-6, 2001.

[3] Radziemska, E. "The effect of temperature on the power drop in crystalline silicon solar cells". Renewable Energy 28 (2003) 1-12. www.elsevier.com/locate/renene.

[4] Skoplaki, E. Palyvos, J.A. "On the temperature dependence of photovoltaic module electrical performance: A review of efficiency/power correlations." Solar Energy 83 (2009) 614-624.

[5] Milosavljevic, D.D. Mirjanic, D. LJ. Pavlovic, T.M. Divnic, D.M. Pirsl, D.S. "Energy Efficiency of PV Solar Plant in real climate conditions in Banja Luka." ThermalScience.January2015.DOI:10.2298/TSCI1501210 33M. https://www.researchgate.net/publication/ 276512828.

[6] Didier T. Richmond, BC. "Review and recommendations for improving the modelling of building integrated photovoltaic systems." Ninth International IBPSA Conference Montréal, Canada. August 15-18, 2005.

[7] Cotfas. D.T, Cotfas. P.A. and Machidon. O. M. "Study of Temperature Coefficients for Parameters of Photovoltaic Cells" Hindawi International Journal of Photoenergy, Volume 2018, Article ID 5945602, 12 pages. https://doi.org/10.1155/2018/5945602.

[8] Kamuyu. W. C. L. Lim, J.R. Won, C.S. Ahn, H. K. "Prediction model of Photovoltaic Module Temperature for Power Performance of Floating PVs.” Energies. 2018, 11,447; doi:10.3390/en11020447.

[9] Kozak, T. Maranda, W. Napieralski, A. Mey, G. D. and Vos, A. D. 2009. "Influence of Ambient Temperature on the Amount of Electric Energy Produced by Solar Modules". 16th International Conference on Mixed Design of Integrated Circuits and Systems, Poland.

[10] Babatunde, A. A. Abbasoglu, S. "Evaluation of field data and simulation results of a photovoltaic system in countries with high solar radiation". Turkish Journal of Electrical Engineering \& Computer Sciences. DOI: 10.3906/elk1402313.http://journals.tubitak.gov.tr/elektrik/ 
[11] Touati, F. Massoud, Hamad, A. J. A. Saeed, S.A. "Effects of Environmental and Climatic Conditions on PV Efficiency in Qatar." International Conference on Renewable Energies and Power Quality (ICREPQ'13) Bilbao (Spain), 20th to 22th March 2013. Renewable Energy and Power Quality Journal (RE\&PQJ) ISSN 2172038 X, No.11, March 2013.

[12] Mazzeo, D. Matera, N. Bevilacqua, P. Arcuri, N. "Energy and economic analysis of solar photovoltaic plants located at the university of Calabria". International journal of heat and technology. Vol.33 (2015), No.4, pp.41-50. http://dx.doi.org/10.18280/ijht.330406.

[13] Bhattacharya, T. Chakraborty, A. K. Pal, K. "Effects of Ambient Temperature and Wind Speed on Performance of Monocrystalline Solar Photovoltaic Module in Tripura, India." Hindawi Publishing Corporation. Journal of Solar Energy. Volume 2014, Article ID 817078, 5 pages. http://dx.doi.org/10.1155/2014/817078.

[14] Garg, S. and JB, Arun. 2019. “The Defining Positive Role of High Cell Temperature on the Performance of a Multicrystalline Solar Photovoltaic Module." Communications on Applied Electronics (CAE) - ISSN:
2394-4714 Volume 7- No. 28, May 2019 www.caeaccess.org.

[15] Dinçer. F, Meral. M.E. "Critical Factors that Affecting Efficiency of Solar Cells." Smart Grid and Renewable Energy, 2010, 1, 47-50.

[16] February 2010. http://en.wikipedia.org/wiki/Solar_cell.

[17] Amin. N, Lung. C.W, Sopian. K. "A practical field study of various solar cells on their performance in Malaysia." Renewable Energy 34 (2009) 1939-1946.

[18] Ghazali M. A, Malek. A, Rahman. A. "The Performance of Three Different Solar Panels for Solar Electricity Applying Solar Tracking Device under the Malaysian Climate Condition." Energy and Environment Research; Vol. 2, No. 1; 2012.ISSN 1927-0569 E-ISSN 1927-0577. Published by Canadian Center of Science and Education. DOI:10.5539/eer.v2nlp235.http://doi.org/10.5539/eer.v2nl p235.

[19] Photovoltaics Report, Prepared by Fraunhofer Institute for Solar Energy Systems, ISE with support of PSE Conferences \& Consulting GmbH Freiburg, 27 August 2018. www.ise.fraunhofer.de. 